\title{
Growth and specific P-uptake rates of bacterial and phytoplanktonic communities in the Southeast Pacific (BIOSOPE cruise)
}

\author{
S. Duhamel ${ }^{1,2}$, T. Moutin ${ }^{1}$, F. Van Wambeke ${ }^{2}$, B. Van Mooy ${ }^{3}$, P. Rimmelin ${ }^{1}$, P. Raimbault ${ }^{1}$, and H. Claustre ${ }^{4}$ \\ ${ }^{1}$ Aix-Marseille Université, Laboratoire d'Océanographie et de Biogéochimie, LOB-UMR 6535 CNRS, OSU/Centre \\ d'Océanologie de Marseille, 13288 Marseille, Cedex 09, France \\ ${ }^{2}$ Aix-Marseille Université, Laboratoire de Microbiologie, Géochimie et Ecologie Marines, LMGEM-UMR 6117 CNRS, \\ OSU/Centre d'Océanologie de Marseille, 13288 Marseille, Cedex 09, France \\ ${ }^{3}$ Department of Marine Chemistry and Geochemistry, Wood Hole Oceanographic Institution, MS \#4, Wood Hole, MA 02543, \\ USA \\ ${ }^{4}$ CNRS, Laboratoire d'océanographie de Villefranche, 06230 Villefranche-sur-Mer, France; Université Pierre et Marie \\ Curie-Paris 6, Laboratoire d'océanographie de Villefranche, 06230 Villefranche-sur-mer, France
}

Received: 15 June 2007 - Published in Biogeosciences Discuss.: 27 June 2007

Revised: 18 September 2007 - Accepted: 18 October 2007 - Published: 8 November 2007

\begin{abstract}
Predicting heterotrophic bacteria and phytoplankton specific growth rates $(\mu)$ is of great scientific interest. Many methods have been developed in order to assess bacterial or phytoplankton $\mu$. One widely used method is to estimate $\mu$ from data obtained on biomass or cell abundance and rates of biomass or cell production. According to Kirchman (2002), the most appropriate approach for estimating $\mu$ is simply to divide the production rate by the biomass or cell abundance estimate. Most methods using this approach to estimate $\mu$ are based on carbon (C) incorporation rates and $\mathrm{C}$ biomass measurements. Nevertheless it is also possible to estimate $\mu$ using phosphate $(\mathrm{P})$ data. We showed that particulate phosphate (PartP) can be used to estimate biomass and that the $\mathrm{P}$ uptake rate to PartP ratio can be employed to assess $\mu$. Contrary to other methods using $\mathrm{C}$, this estimator does not need conversion factors and provides an evaluation of $\mu$ for both autotrophic and heterotrophic organisms. We report values of P-based $\mu$ in three size fractions $(0.2-0.6$; $0.6-2$ and $>2 \mu \mathrm{m}$ ) along a Southeast Pacific transect, over a wide range of P-replete trophic status. P-based $\mu$ values were higher in the $0.6-2 \mu \mathrm{m}$ fraction than in the $>2 \mu \mathrm{m}$ fraction, suggesting that picoplankton-sized cells grew faster than the larger cells, whatever the trophic regime encountered. Picoplankton-sized cells grew significantly faster in the deep chlorophyll maximum layer than in the upper part of the photic zone in the oligotrophic gyre area, suggesting that picoplankton might outcompete $>2 \mu \mathrm{m}$ cells in this particular high-nutrient, low-light environment. P-based $\mu$ attributed to free-living bacteria $(0.2-0.6 \mu \mathrm{m})$ and picoplankton $(0.6-$ $2 \mu \mathrm{m})$ size-fractions were relatively low $\left(0.11 \pm 0.07 \mathrm{~d}^{-1}\right.$ and

Correspondence to: S. Duhamel

(solange.duhamel@univmed.fr)
\end{abstract}

$0.14 \pm 0.04 \mathrm{~d}^{-1}$, respectively) in the Southeast Pacific gyre, suggesting that the microbial community turns over very slowly.

\section{Introduction}

A fundamental aim in ecology and hence, biological oceanography and limnology, is to understand and predict the abundance of organisms and their temporal change (Banse, 2002). An assessment of the ecological role of both autotrophic and heterotrophic marine micro-organisms depends, to a significant extent, on estimates of their specific growth rate $(\mu)$ (Azam et al., 1983). Bacterial or primary production is the synthesis of bacteria or phytoplankton biomass, respectively. Production can be expressed as the rate of synthesis of cells or cell mass: production $=\mu \times$ biomass, where $\mu$ is the specific growth rate of the population expressed in units of inverse time $t^{-1}$ (Ducklow, 2000). Phytoplankton $\mu$ estimates vary widely from values of around 0.1-0.3 $\mathrm{d}^{-1}$ (Letelier et al., 1996; Marañon et al., 2000, 2005) to $1-2 \mathrm{~d}^{-1}$ (Laws et al., 1987; Quevedo and Anadon, 2001). Bacterial $\mu$ estimates also vary widely, from very low values $0.004-0.25 \mathrm{~d}^{-1}$ (Sherr et al., 2001; Van Wambeke, 2007b) to higher values of around 2$10 \mathrm{~d}^{-1}$ (Ducklow, 1983; Jones et al., 1996). Studies comparing bacterial and phytoplankton $\mu$ are scarce and show significant differences between bacterial and phytoplankton $\mu$ (Jones et al., 1996).

Numerous methods have been developed to measure $\mu$ (Brock, 1971). Direct and indirect methodologies of varying accuracy have been used to estimate phytoplankton and

Published by Copernicus Publications on behalf of the European Geosciences Union. 
heterotrophic bacterial $\mu$. The two most common direct methods, applicable to both heterotrophic bacteria and phytoplankton, are (1) to observe the frequency of dividing cells (Hagstrom et al., 1979) and (2) the dilution technique (Landry and Hassett, 1982; Quevedo and Anadon, 2001). Direct methods are difficult to set up on board so microbial growth rates are commonly calculated from production and standing stock data (Ducklow, 2000). According to Kirchman (2002), the most appropriate approach for estimating $\mu$ of microbial assemblages is the simplest, that is, dividing the production rate by the biomass estimate (B). This ratio called the "specific uptake rate" $\left(\mathrm{V}^{\mathrm{sp}}\right)$ is a carbon $(\mathrm{C})$, nitrogen $(\mathrm{N})$ or phosphate (P)-based measurement of $\mu$ corresponding to the cell specific or biomass specific uptake of $\mathrm{C}, \mathrm{N}$ or $\mathrm{P}$ (Lipschultz, 1995; Dickson and Wheeler, 1995; Ducklow, 2000). $\mathrm{V}^{\mathrm{sp}}$ is an expression of the $\mu$. These two parameters are not necessarily equal and $\mathrm{V}^{\mathrm{sp}}$ must be considered as an estimator of $\mu$. Both $\mu$ and $\mathrm{V}^{\mathrm{sp}}$ are determined by resource limitation, temperature and predation (Brock, 1971; Thingstad, 2000). The most common indirect methods for measuring phytoplankton $\mu$ are ${ }^{14} \mathrm{C}$-pigment labelling (Redalje and Laws, 1981; Welschmeyer et al., 1991; Jones et al., 1996; Cailliau et al., 1996), cell cycle analysis (Vaulot, 1992; Liu et al., 1999) and the use of equations linking autotrophic production (AP) and autotrophic cell abundance or biomass (AB) (Smith et al., 2000; Marañon, 2005). In such equations, AP is deduced from $\mathrm{NaH}^{14} \mathrm{CO}_{3}$ incorporation rate measurements (Steemann-Nielsen, 1951) in the particulate fraction (i.e. biomass production) which does not include significant losses from respiration or excretion, when short term incubations are processed. The most common indirect method for studying heterotrophic bacterial $\mu$ is the use of equations linking heterotrophic bacterial production (HBP) and heterotrophic bacterial cell abundance or biomass (HBB). In such equations, HBP is generally deduced from the incorporation of ${ }^{3} \mathrm{H}$-thymidine (Fuhrman and Azam, 1980, 1982) and ${ }^{3} \mathrm{H}$-leucine (Kirchman et al., 1985) into DNA and proteins, respectively, with appropriate conversion factors for biomass production. More recently, measurements of the incorporation rates of ${ }^{33} \mathrm{PO}_{4}$ into phospholipids (particularly phosphatidylglycerol: $\mathrm{PG}$ and phosphatidylethanolamine: PE) specific to bacterioplankton have been used (Van Mooy et al., 2006).

Phytoplankton $\mu$ is frequently estimated by dividing AP (measured using the ${ }^{14} \mathrm{C}$ method) by various $\mathrm{AB}$ estimators such as Chlorophyll a (Chla), particulate organic carbon (POC) and C content using microscopy or flow cytometry measurements (Eppley, 1972; Vadstein et al., 1988; Malone et al., 1993; Marañon et al., 2000, 2005; Moreira-Turcq, 2001). The use of Chla and POC as AB proxies is debatable (Le Floc'h et al., 2002; Sobczak et al., 2002; Huot et al., 2007) and C content estimates are dependant on conversion factors. These conversion factors can vary greatly between studies. Similarly, the evaluation of bacterial $\mu$ based on the HBP to HBB ratio requires the use of sev- eral conversion factors (to convert the incorporation of ${ }^{3} \mathrm{H}-$ leucine or ${ }^{3} \mathrm{H}$-thymidine to $\mathrm{C}$ equivalents and to convert cell number to biomass equivalents). These conversion factors vary with different studies (Riemann et al., 1990). Furthermore, method comparisons can show significant differences between $\mu$ estimates (Laws et al., 1984).

If $\mu=$ production/biomass, then there is a direct relationship between incorporation rate per cell and $\mu$ (Kirchman, 2002). Although biomass and production estimators are usually expressed in terms of $\mathrm{C}$, it is also possible to express them in terms of $\mathrm{N}$ or $\mathrm{P}$ as $\mathrm{C}, \mathrm{N}$ and $\mathrm{P}$ are major cellular constituents linked via the "Redfield ratio" (Redfield, 1963; Berman, 1980; Laws et al., 1984). PartP is released from decaying material more efficiently than $\mathrm{C}$ and $\mathrm{N}$ (Loh and Bauer, 2000) and seems to be decomposed or remineralized essentially at the same rate as chlorophyll (Menzel and Ryther, 1964). As a consequence, in the open ocean, the proportion of detrital P in PartP is low (Faul et al., 2005). Phosphate uptake rates are commonly measured using the ${ }^{32} \mathrm{P}$ or ${ }^{33} \mathrm{P}$ method, which quantifies the amount of $\mathrm{P}$ that is taken up by both heterotrophic and autotrophic cells. Measuring the dissolved inorganic P (DIP) uptake rates provides an estimate for planktonic production, assuming DIP is the sole source of $\mathrm{P}$ and there is no, or negligible luxury uptake (Thingstad et al., 1996). Thus, particulate $\mathrm{P}$ (PartP) and $\mathrm{P}$ uptake rate can be used as estimators of planktonic biomass and production, respectively.

We estimated $\mu$ from production to biomass ratios expressed in terms of $\mathrm{P}$ and discussed the bias associated with using $\mathrm{C}$ and $\mathrm{P}$-based $\mu$ estimations. Combining $\mathrm{P}$ uptake rates and PartP measurements with size fractionations, we determined the DIP specific uptake rate $\left(\mathrm{V}_{\mathrm{DIP}}^{\mathrm{sp}}\right)$ in three size fractions corresponding to heterotrophic bacteria, picophytoplankton and nano-microphytoplankton $(0.2-0.6 ; 0.6-2$ and $>2 \mu \mathrm{m}$, respectively), following an East-West transect along the Southeast Pacific ocean. This area presents a gradient in trophic conditions, from the extremely oligotrophic Southeast Pacific gyre, the largest and most poorly investigated province of the world ocean (Claustre and Maritorena, 2003; Claustre et al., $2007^{1}$ ), to the highly productive Chilean upwelling region. The measurement of $\mathrm{V}_{\mathrm{DIP}}^{\mathrm{sp}}$ in the different fractions enabled us to compare bacterial to phytoplankton $\mu$ using the same method and enabled us to study the variation in dynamics between 2 major groups of phytoplankton.

\footnotetext{
${ }^{1}$ Claustre, H., Sciandra, A., and Vaulot, D.: Introduction to the special section: bio-optical and biogeochemical conditions in the South East Pacific in late 2004 - the BIOSOPE cruise, Biogeosciences, in preparation, 2007.
} 


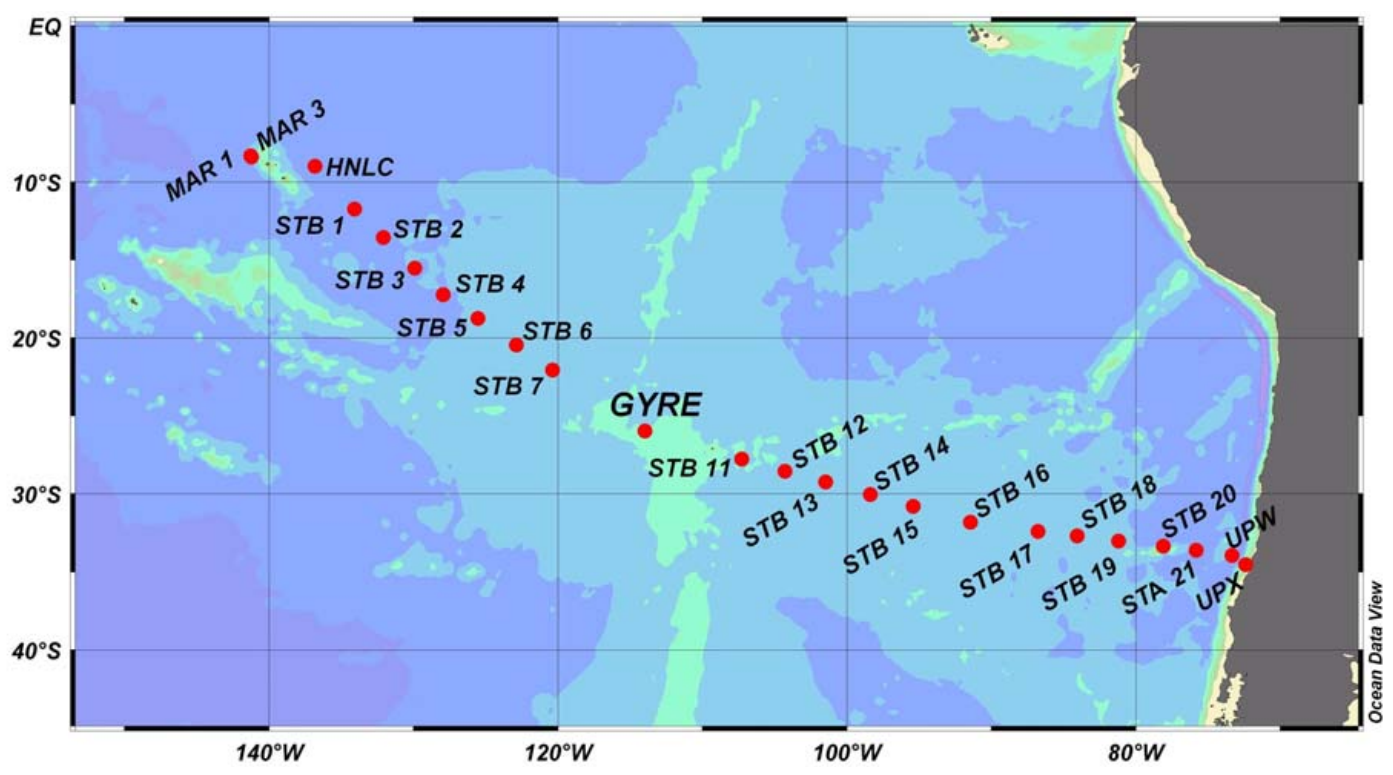

Fig. 1. Station names and locations of the BIOSOPE cruise transect in the South East Pacific Ocean (October-December 2004). MAR 1 and MAR 3 (in the vicinity of Marquesas Islands), HNLC (High Nutrient Low Chlorophyll area), GYRE (the central part of the Southeast Pacific gyre), and UPW and UPX (the Chilean upwelling) are long stations (3-4 days) abbreviated according their location; STB1-STA21 are short stations (1 day).

\section{Materials and methods}

2.1 Station locations, sample collection and hydrological characteristics

This work was conducted during the BIOSOPE (BIogeochemistry and Optics SOuth Pacific Experiment) cruise in the Southeast Pacific Ocean (between $146.36^{\circ} \mathrm{W}$ and $72.49^{\circ} \mathrm{W}$; Fig. 1). The cruise was carried out aboard "l'Atalante" from October to December 2004. High resolution profiles of temperature, conductivity, salinity, oxygen and fluorescence were obtained using a CTDO profiler (Seabird 911 Plus) from a depth of 0 to $500 \mathrm{~m}$ (See Claustre et al. and Ras et al., 2007, for hydrodynamical entities, hydrographic conditions and pigment distribution). Seawater samples were collected at 6 different depths corresponding to 50, 25, 15, 7,3 and $1 \%$ surface irradiance, respectively. Samples were collected in 121 Niskin bottles attached to a rosette CTD system, at 09:00 a.m. (local time). Subsamples were collected without pre-filtration, into clean, sample-rinsed polycarbonate bottles.

\subsection{Analytical methods}

Particulate phosphate (PartP) was measured using the Strickland and Parsons procedure (1972) for standard DIP, following high-temperature persulfate wet-oxidation at $120^{\circ} \mathrm{C}$ and 1 bar (Pujo-Pay and Raimbault, 1994). Sequential filtration was carried out on 1 to 1.21 samples through different porosity polycarbonate filters $(0.2,0.6$, and $2 \mu \mathrm{m} ; 47 \mathrm{~mm})$ using Sartorius systems and very low vacuum (drop by drop). The
0.2 and $0.6 \mu \mathrm{m}$ filters in the lower Sartorius system were separated by a nylon separator (NY8H04700, Millipore) previously treated using persulfate wet-oxidation to lower blank values. Immediately after filtration, the filters (and the separator for the $0.2 \mu \mathrm{m}$ filter) were put into $20 \mathrm{ml}$ Teflon bottles. $2.5 \mathrm{ml}$ of reagent $\left(140 \mathrm{ml}\right.$ of $\mathrm{NaOH} 1.5 \mathrm{M}, 30 \mathrm{~g}$ of $\mathrm{H}_{3} \mathrm{BO}_{3}$, $360 \mathrm{ml}$ of demineralised water) was added and the mineralization processed (autoclave $30 \mathrm{~min}, 1 \mathrm{bar}$ ). After cooling down to ambient temperature, DIP was measured in the same bottles. All reagents were prepared with pro analysis MerckTM Reagent Grade chemicals and with Milli-QTM high purity demineralised water. All utensils were washed with $10 \%$ hydrochloric acid and rinsed three times with demineralised water.

Particulate organic carbon concentration was determined by the wet-oxidation procedure (Raimbault et al., 1999), following the filtration of 1.21 of seawater through $0.2 \mu \mathrm{m}$ teflon membranes.

Chlorophyll a (Chl a) concentration was determined by the serial filtration of 1 to 1.21 samples following the same filtration method as for PartP. Immediately after filtration, the filters were put in cryotubes with $5 \mathrm{ml}$ of methanol for pigment extraction $\left(30 \mathrm{~min}, 4^{\circ} \mathrm{C}\right)$ (Herbland et al., 1985). The fluorescence was measured using a Turner designs 10-AU-005CE fluorimeter equipped with a chlorophyll a Kit (F4T45.B2 lamp) according to Welschmeyer (1994).

Picophytoplankton (Prochlorococcus, Synechococcus and picophytoeukaryotes) and bacterial abundance were determined according to Grob et al. (2007) using a FACSCalibur (Becton Dickinson) flow cytometer. Picophytoplankton 
abundance was determined in situ on fresh samples while bacterioplankton samples were fixed with a final concentration of either $1 \%$ paraformaldehyde or $0.1 \%$ glutaraldehyde and frozen in liquid nitrogen. Samples were then processed according to Marie et al. (2000a,b). At each sampling depth, defined by the Chla and $\mathrm{P}$ and $\mathrm{C}$ uptake rates measurements, $2 \mathrm{~mL}$ samples were filtered through $0.6 \mu \mathrm{m}$ polycarbonate filters. The filtrate was then analysed using flow cytometry and compared to the total in the corresponding sample.

Carbon and phosphate uptakes were determined using the ${ }^{33} \mathrm{P} /{ }^{14} \mathrm{C}$ dual labelling method (Duhamel et al., 2006). Duplicate samples $(300 \mathrm{ml})$ were collected into samplerinsed, polycarbonate bottles (Nalgene) for each sampling depth. An additional duplicate sample $(300 \mathrm{ml})$ of surface water was incubated with $300 \mu \mathrm{l}$ of $\mathrm{HgCl}_{2}\left(20 \mathrm{gl}^{-1}\right)$ to act as a control for non-biological assimilation (Kirkwood 1992). The samples were inoculated with $1080 \mathrm{kBq}$ carrierfree ${ }^{33} \mathrm{P}\left(<40 \mathrm{pmol} \mathrm{l}^{-1}\right.$ final concentration - orthophosphate in dilute hydrochloric acid; Amersham BF 1003; half-life $25.383 \pm 0.040$ days; Duhamel et al., 2006), and 3.7 MBq ${ }^{14} \mathrm{C}$ (bicarbonate aqueous solution; Amersham CFA3; half-life $5700 \pm 30$ years; Duhamel et al., 2006). Samples were incubated under simulated conditions for 4 to $5 \mathrm{~h}$. Incubation boxes equipped with light filters (nickel screens) were used to reproduce the light level at the sample depths (50 $-25-15-7-3-1 \%$ of transmitted light). Following incubation, $600 \mu \mathrm{l}$ of $\mathrm{KH}_{2} \mathrm{PO}_{4}\left(10 \mathrm{mmol} \mathrm{l}^{-1}\right)$ was added to each flask in order to stop labelled DIP assimilation. Samples were kept in the dark to stop DIC uptake. Fractions of $50 \mathrm{ml}$ were filtered through $25 \mathrm{~mm}$ polycarbonate membranes $(0.2,0.6$ and $2 \mu \mathrm{m})$ which had been placed on $\mathrm{GF} / \mathrm{F}$ filters soaked with saturated $\mathrm{KH}_{2} \mathrm{PO}_{4}$, using a low-pressure suction $(<0.2$ bars). When all samples were filtered, the pressure was increased to 0.6 bars for $5 \mathrm{~s}$ in order to eliminate unincorporated ${ }^{33} \mathrm{P}$. Filters were placed into scintillation vials (Wheaton low-potassium $6 \mathrm{ml}$ glass-clear vials with screwcap foil liner) with $150 \mu \mathrm{l}$ of $\mathrm{HCl}\left(0.5 \mathrm{moll}^{-1}\right)$ in order to eliminate any un-incorporated ${ }^{14} \mathrm{C}$. After $12 \mathrm{~h}, 6 \mathrm{ml}$ of scintillation liquid (Ultimagold MV scintillation liquid, Packard) was added to each vial before the first count. Counting (count per minute - cpm) was carried out on a Packard Tri-Carb ${ }^{\circledR}$ 2100TR scintillation counter. In order to separate the activity due to ${ }^{33} \mathrm{P}$ from that of ${ }^{14} \mathrm{C}$, we applied the method using the different half-lives of the two isotopes (For more details, see Duhamel et al., 2006). A second count was made a year later, samples having been preserved in the dark at room temperature. $\mathrm{C}$ and $\mathrm{P}$ uptake rate measurements in each size fraction $(0.2-0.6 ; 0.6-2$ and $>2 \mu \mathrm{m})$ were obtained using difference calculations.

Bacterial production was determined by $\left[{ }^{3} \mathrm{H}\right]$-leucine incorporation using the centrifugation method (Smith and Azam, 1992) according to Van Wambeke et al. (2007b). A factor of $1.5 \mathrm{~kg} \mathrm{C} \mathrm{mol} \mathrm{leucine}{ }^{-1}$ was used to convert the incorporation of leucine to carbon equivalents, assuming no isotopic dilution (Kirchman, 1993).

\subsection{Daily rates}

The daily $\mathrm{C}$ uptake rates have been calculated using the method of Moutin et al. (1999). The model enables a conversion factor to be calculated which permits net hourly DIC uptake rates $\left(\mathrm{nmol} \mathrm{l}^{-1} \mathrm{~h}^{-1}\right)$ to be transformed into net daily rates $\left(\mathrm{nmoll}^{-1} \mathrm{~d}^{-1}\right)$. The model takes into account the geographical position (latitude and longitude), the sampling date, the time of dawn, incubation start time and the time the incubation ended (GMT). The model of Moutin et al. (1999) that previously took theoretical solar radiation into account has been modified to take into account the surface irradiance measured on board.

Daily P uptake rates have been calculated simply by multiplying the hourly rate by 24 . Indeed, in several studies (Perry and Eppley, 1981; Moutin et al., 2002), P uptake was shown to be constant over $24 \mathrm{~h}$.

\subsection{Specific uptake rate estimates}

Specific uptake rates $\left(\mathrm{V}^{\mathrm{sp}}\right)$ have been calculated by dividing heterotrophic bacterial production (HBP), $\mathrm{C}$ uptake rates $\left(\mathrm{V}_{\text {DIC }}\right)$ or $\mathrm{P}$ uptake rates $\left(\mathrm{V}_{\mathrm{DIP}}\right)$ by heterotrophic bacterial biomass (HBB), phytoplankton biomass (AB) and particulate $\mathrm{P}$ (PartP), respectively. $\mathrm{V}_{\mathrm{DIP}}^{\mathrm{sp}}$ corresponds to the $\mathrm{V}_{\mathrm{DIP}}$ to PartP ratio, $\mathrm{V}_{\mathrm{DIC}}^{\mathrm{sp}}$ corresponds to the $\mathrm{V}_{\mathrm{DIC}}$ to $\mathrm{AB}$ ratio, HBP:HBB corresponds to the HBP to HBB ratio. A conversion factor of $10 \mathrm{fgC} \mathrm{cell}^{-1}$ (Christian and Karl, 1994; Caron et al., 1995) has been used to convert heterotrophic bacterial abundance (counted by flow cytometry) to $\mathrm{C}$ equivalent. $\mathrm{AB}$ has been calculated using two methods. The first one uses a cell-number-to-biomass conversion factor. We chose the Campbell et al. (1997) estimates for Prochlorococcus, Synechococcus and Picoeukaryotes (Table 1). The second method uses a Chla-to-biomass conversion factor. For stations outside the gyre, we chose $70 \mathrm{gC} \mathrm{gChla}^{-1}$, the average value found for subtropical Atlantic Ocean total phytoplankton (Veldhuis and Kraay, 2004). For stations inside the gyre, we used a Chla-to-biomass conversion factor varying with PAR (Photosynthetically Active irradiance): 185, 120, 90, and $20 \mathrm{gC} \mathrm{gChla}^{-1}$ for 50 and $25 \%, 15 \%, 7 \%$, and 3 and $1 \%$ of PAR, respectively. These factors were chosen in accordance with the results obtained by Veldhuis and Kraay (2004) at their most oligotrophic station in the Atlantic tropical gyre.

The $\mathrm{V}_{\mathrm{DIP}}^{\mathrm{sp}}$ have been calculated for four size fractions: $0.2-0.6 ; 0.6-2 ;>2$ and $>0.6 \mu \mathrm{m}$. We will develop arguments to show that they correspond to heterotrophic bacteria $\left(\mathrm{V}_{\mathrm{DIP}<0.6}^{\mathrm{sp}}\right)$, picophytoplankton $\left(\mathrm{V}_{\mathrm{DIP} 0.6-2}^{\mathrm{sp}}\right)$, nanomicophytoplankton $\left(\mathrm{V}_{\mathrm{DIP}>2}^{\mathrm{sp}}\right)$ and total phytoplankton $\left(\mathrm{V}_{\mathrm{DIP}}^{\mathrm{sp}}>0.6\right)$, repectively. $\mathrm{V}^{\mathrm{sp}}$ are expressed as daily rates $\left(\mathrm{d}^{-1}\right)$ so are comparable with the values found in the literature. 
Table 1. Review of values of biovolume-to-biomass and cell-number-to-biomass conversion factors.

Biovolume-to-biomass conversion factor

\begin{tabular}{|c|c|c|}
\hline $\begin{array}{l}\text { Biovolume:B } \\
\left(\mathrm{g} \text { of } \mathrm{C} \mathrm{cm}^{-3}\right)\end{array}$ & Organisms - location & Reference \\
\hline 0.121 & Bacteria seawater or cultures & Watson et al., 1977 \\
\hline $0.38 \pm 0.05$ & Heterotrophic bacteria - pebble beach (Long Island) or culture & Lee and Fuhrman, 1987 \\
\hline \multicolumn{3}{|c|}{ Cell-number-to-biomass conversion factor } \\
\hline $\begin{array}{l}\text { Cell:B } \\
(\text { fg of } C \text { cell }\end{array}$ & Organisms - location & Reference \\
\hline $20 \pm 0.8$ & Heterotrophic bacteria - pebble beach (Long Island) or culture & Lee and Fuhrman, 1987 \\
\hline 5.9 to 47.9 & Heterotrophic bacteria - coastal environments & Fukuda et al., 1998 \\
\hline 13 & Heterotrophic bacteria - subtropical Pacific Ocean & Fukuda et al., 1998 \\
\hline 12.4 & Heterotrophic bacteria - Oceanic environments & Fukuda et al., 1999 \\
\hline 10 & Heterotrophic bacteria - subtropical Pacific Ocean & Christian and Karl, 1994 \\
\hline 15 & Heterotrophic bacteria - Sargasso Sea & Caron et al., 1995 \\
\hline 5.83 & Heterotrophic bacteria - Northern Adriatic Sea (warm period) & La Ferla and Leonardi, 2005 \\
\hline 42.17 & Heterotrophic bacteria - Northern Adriatic Sea (cold period) & La Ferla and Leonardi, 2005 \\
\hline 20 & Heterotrophic bacteria - Station ALOHA & Campbell et al., 1997 \\
\hline $65 \pm 67$ & $\begin{array}{l}\text { Prochlorococcus CCMP 1378: considering C content varies } \\
\text { with light for cultures switched from low light to high light }\end{array}$ & Cailliau et al., 1996 \\
\hline $48 \pm 10$ & $\begin{array}{l}\text { Prochlorococcus CCMP 1378: considering C content varies } \\
\text { with light for cultures switched high light to low ligh }\end{array}$ & Cailliau et al., 1996 \\
\hline $49 \pm 9$ & $\begin{array}{l}\text { Prochlorococcus CCMP 1378: considering C content is } \\
\text { independent of light }\end{array}$ & Cailliau et al., 1996 \\
\hline $27 \pm 6$ & Prochlorococcus PCC 9511 grown under a daily light cycle & Claustre et al., 2002 \\
\hline 53 & Prochlorococcus - Station ALOHA & Campbell et al., 1997 \\
\hline 46 & Prochlorococcus - cultures Prochlorococcus MED4 & Bertilsson et al., 2003 \\
\hline 29 & Prochlorococcus - Atlantic transect from $50^{\circ} \mathrm{N}$ to $50^{\circ} \mathrm{S}$ & Zubkov et al., 1998 \\
\hline $279.1 \pm 84.2$ & Synechococcus - cultures Synechococcus WH8102 & Six et al., 2004 \\
\hline 250 & Synechococcus - Station ALOHA & Campbell et al., 1997 \\
\hline 92 & Synechococcus - cultures Synechococcus WH8012 & Bertilsson et al., 2003 \\
\hline 100 & Synechococcus - Atlantic transect from $50^{\circ} \mathrm{N}$ to $50^{\circ} \mathrm{S}$ & Zubkov et al., 1998 \\
\hline 2108 & Picoeukaryote - Station ALOHA & Campbell et al., 1997 \\
\hline 1500 & Picoeukaryote - Atlantic transect from $50^{\circ} \mathrm{N}$ to $50^{\circ} \mathrm{S}$ & Zubkov et al., 1998 \\
\hline
\end{tabular}

\section{Results}

\subsection{Cytometry data}

Bacteria were separated from phytoplankton by filtering through $0.6 \mu \mathrm{m}$ filters so as to determine bacterial $\mathrm{V}_{\mathrm{DIP}}^{\mathrm{sp}}$ in the $0.2-0.6 \mu \mathrm{m}$ fraction. The percentages of bacterial cells passing through a $0.6-\mu \mathrm{m}$-filter were counted using flow cytometry in order to assess the accuracy of the results. On comparing total and $<0.6 \mu \mathrm{m}$ sample counts, we found that on average, $91 \pm 10 \%$ of the heterotrophic bacteria passed through the $0.6-\mu \mathrm{m}$-filter whatever the trophic regime ( $n=90$; all euphotic-layer depths included). This value was in the same range as those obtained in other studies ( $~ 80 \%$; Obernosterer et al., 2003). Flow cytometry mea- surements revealed that Prochlorococcus (when detectable), Synechococcus and Picoeucaryotes cells had an average size of $0.68 \pm 0.08 \mu \mathrm{m} ; 0.86 \pm 0.1 \mu \mathrm{m}$ and $1.74 \pm 0.13 \mu \mathrm{m}$, respectively over the entire transect (Results from Grob et al., 2007). The average cell size of Synechococcus found at the upwelling stations was $1.16 \pm 0.02 \mu \mathrm{m}$. Despite of this, cytometry counts showed that $34 \pm 24 \%$ of the Prochlorococcus cells and $3 \pm 5 \%$ of the Synechococcus cells were found in the $<0.6 \mu \mathrm{m}$ fraction.

3.2 Evaluating the use of particulate phosphate as an estimator of living biomass

Figure 2 shows a typical example of the vertical distribution of PartP and Chla concentrations compared to the vertical 


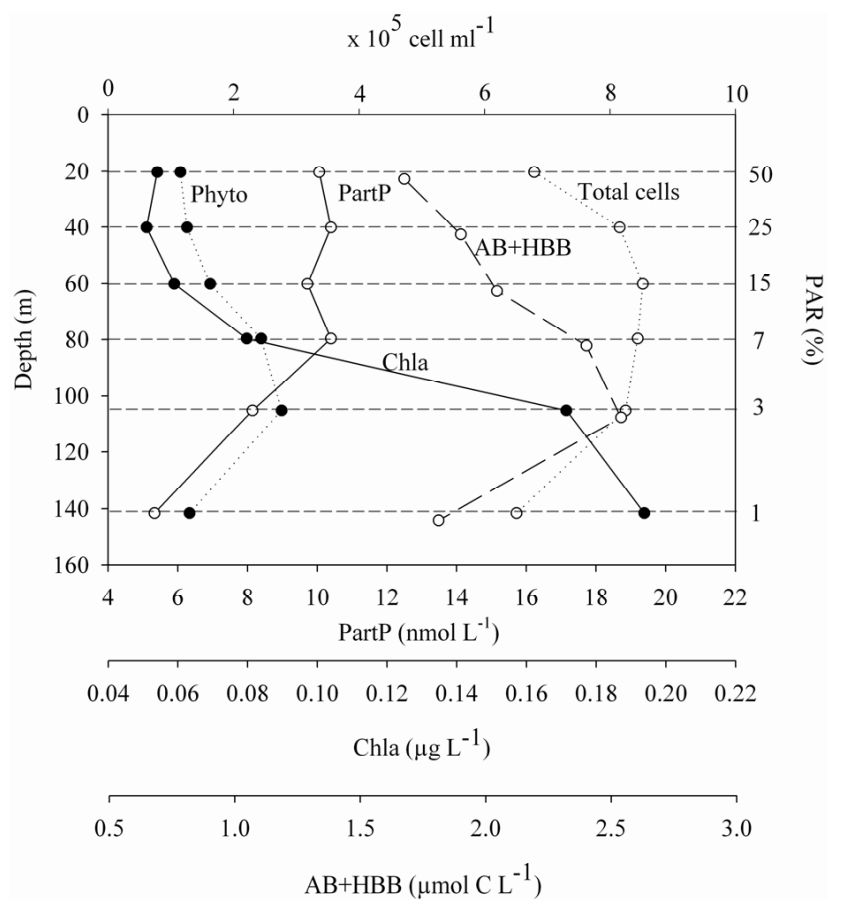

Fig. 2. Example of vertical distribution of biological properties at station STB4 $\left(127.97^{\circ} \mathrm{W} ; 17.23^{\circ} \mathrm{S}\right)$ : particulate phosphate (PartP), chlorophyll a (Chla), total phytoplankton counted by flow cytometry: Prochlorococcus + Synechococcus + picoeucaryotes (phyto), total cells (heterotrophic bacteria + phytoplankton) counted by flow cytometry (Total cells) and total $\mathrm{C}$ biomass estimates based on cell counts $(\mathrm{AB}+\mathrm{HBB})$.

distribution of cell counts by flow cytometry and total $\mathrm{C}$ biomass estimate based on cell counts $(\mathrm{AB}+\mathrm{HBB})$. In the upper $80 \mathrm{~m}$, PartP concentrations were fairly constant, varying between 10.0 and $10.4 \mathrm{nmol}^{-1}$ from the surface to a depth of $7 \%$ PAR. PartP concentrations decreased to $5.3 \mathrm{nmol}^{-1}$ at the depth of $1 \%$ PAR while Chla concentrations increased from 0.05 to $0.19 \mu \mathrm{gl}^{-1}$ from the surface waters down to $1 \%$ of PAR, respectively. In contrast to Chla, PartP did not show a deep concentration maximum (Fig. 2). Phytoplankton cell counts using flow cytometry showed an increase from $1.1 \times 10^{5}$ to $2.8 \times 10^{5}$ cells ml $^{-1}$ from surface water to the depth of $3 \%$ of PAR and a decrease to $1.3 \times 10^{5}$ cells ml ${ }^{-1}$ at the depth of $1 \%$ of PAR. In the same way, total cytometric counts (bacteria + phytoplankton) showed an increase from $6.8 \times 10^{5}$ to $8.5 \times 10^{5}$ cells ml $^{-1}$ from the surface water to the depth of $15 \%$ of PAR and a decrease to $6.5 \times 10^{5}$ cells ml $^{-1}$ at the depth of $1 \%$ of PAR. The total $\mathrm{C}$ biomass $(\mathrm{AB}+\mathrm{HBB})$ estimated from cell counts using flow cytometry and conversion factors from Campbell et al. (1997) for the different groups of organisms (heterotrophic bacteria, Prochlorococcus, Synechococcus and picoeukaryotes) increased between 50 and 3\% of PAR, ranging from 1.68 to $2.64 \mu \mathrm{mol} \mathrm{Cl}^{-1}$, before decreasing to $1.81 \mu \mathrm{mol} \mathrm{Cl} 1^{-1}$. Variations in PartP concentration throughout the euphotic zone are closer to that of

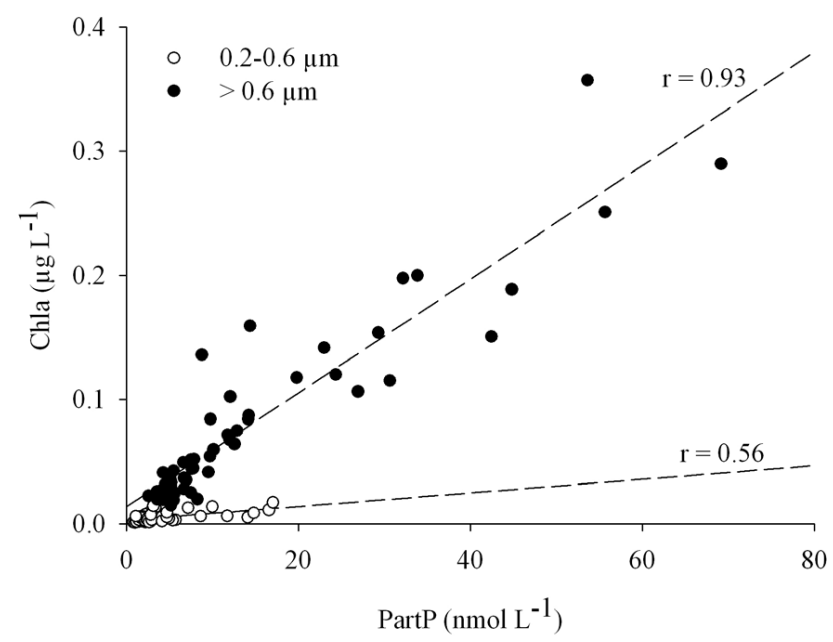

Fig. 3. Relations between Chlorophyll a (Chla) and particulate phosphate (PartP) at depth corresponding to a range of PAR levels between $50 \%$ and $15 \%$, for two size fractions: $0.2-0.6 \mu \mathrm{m}$ and $>0.6 \mu \mathrm{m}$.

cell concentration and total $\mathrm{C}$ biomass, estimate based on cell counts, than to Chla concentration.

Chla is largely used to estimate phytoplankton biomass (Trembaly and Legendre, 1994; Uitz et al., 2006). However, as illustrated in Fig. 2, the C:Chla ratio varies with light (Taylor et al., 1997). In comparing biomass estimates to Chla concentration only data between 50 and $15 \%$ of transmitted light have been considered to avoid any bias associated with photoacclimatation. PartP and Chla data were compared in the $<0.6$ and $>0.6 \mu \mathrm{m}$ fractions (Fig. 3) in order to verify that the PartP in these fractions was representative of the bacteria and phytoplankton biomasses, respectively. Most of the PartP in the $>0.6 \mu \mathrm{m}$ fraction correlated to Chla, supporting the hypothesis that it is essentially made up of phytoplankton biomass (Fig. 3). The relationship between Chla and PartP in the $0.2-0.6 \mu \mathrm{m}$ fraction was less significant than in the $>0.6 \mu \mathrm{m}$ fraction $(\mathrm{r}=0.56, \mathrm{P}<0.001$; and $\mathrm{r}=0.93, \mathrm{P}<0.001$, respectively; Fig. 3), indicating that PartP variability (69\% and $14 \%$, respectively) is not related to Chla variability in the $0.2-0.6 \mu \mathrm{m}$ fraction. Indeed, the Prochlorococcus cells that passed through the $0.6 \mu \mathrm{m}$ filter contributed to PartP and Chla concentrations in the $0.2-0.6 \mu \mathrm{m}$ fraction, but the correlation between these two parameters is comparatively weak and indicates that it is mainly free-living bacteria (i.e. organisms that do not contain Chla) that contribute to PartP in this $<0.6 \mu \mathrm{m}$ fraction.

Menzel and Ryther (1964) determined the detrital proportion of PartP using a regression between PartP, particulate $\mathrm{C}$ and Chla, for the same group of samples. We made such comparisons (Fig. 4a, c, d; eutrophic stations have been omitted to avoid regressions being drawn by high values.). The correlation between Chla and PartP concentration data was better $(r=0.87, p<0.001$, Fig. $4 c)$ than that between Chla and 

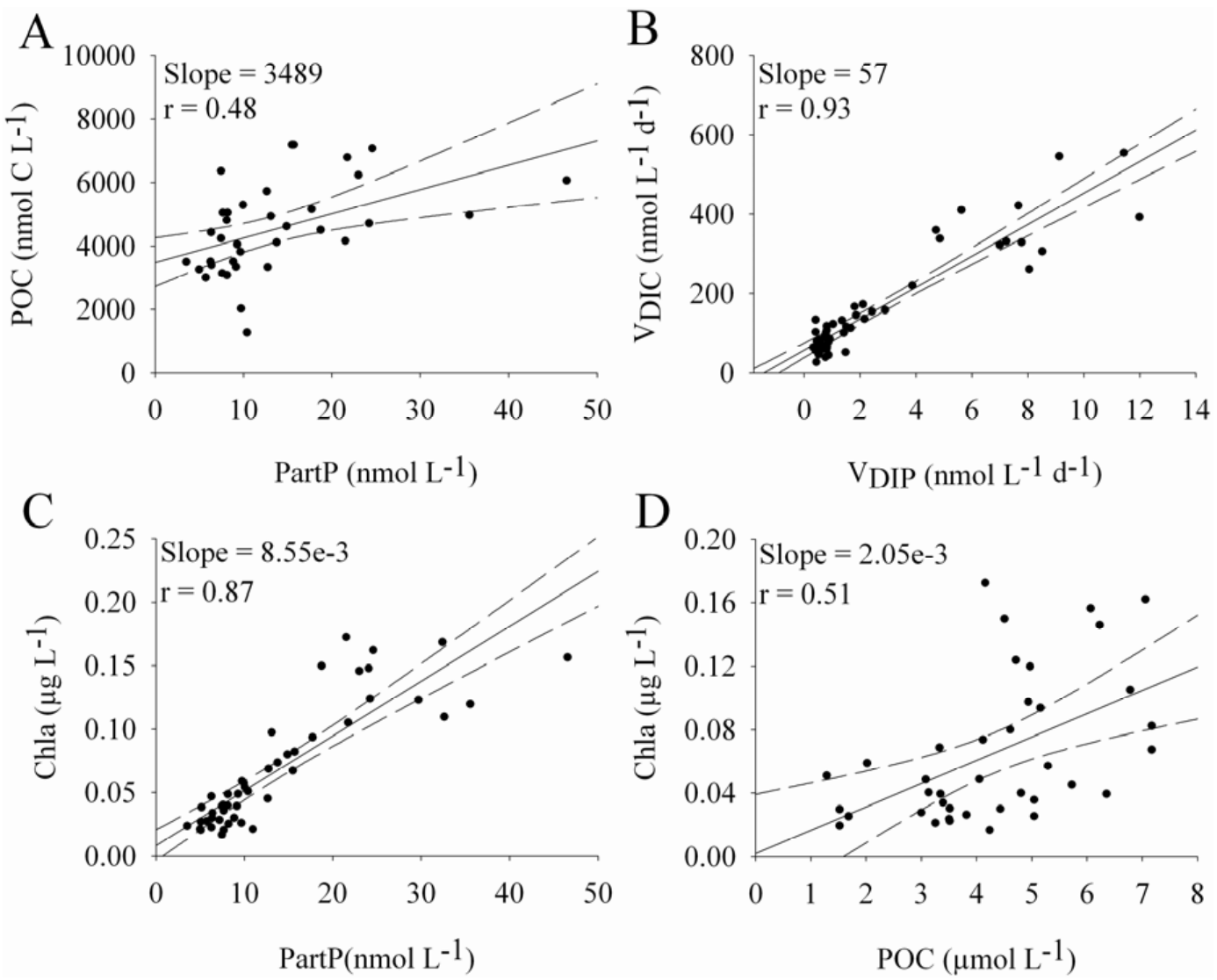

Fig. 4. Relations between particulate carbon (POC) and phosphate (PartP) (A), between carbon $\left(\mathrm{V}_{\mathrm{DIC}}\right)$ and phosphate $\left(\mathrm{V}_{\mathrm{DIP}}\right)$ uptake rates (B) between chlorophyll a (Chla) and PartP (C) and between Chla and POC (D). Data from 50 to $15 \%$ of PAR and between HNLC and STB18 stations. "slope" and " $r$ " corresponds to the slope and the regression coefficient, respectively. The dotted lines correspond to the $95 \%$ confident range of the regression line (full line).

POC ( $r=0.51, p<0.05$, Fig. 4d), supporting the hypothesis that PartP is a better indicator of living biomass than POC. As found by Menzel and Ryther (1964), the regressions between PartP and POC, when extrapolated toward the origin, indicated significant amounts of $\mathrm{C}$ in the absence of $\mathrm{P}$ whilst the regression between PartP and Chla intercepted at the origin, indicating that Chla and PartP were decomposed or mineralized at essentially the same rate, whilst POC was more refractory. The comparison of the regression slope between POC and PartP concentration and between $\mathrm{V}_{\text {DIC }}$ and $\mathrm{V}_{\text {DIP }}$ (Fig. 4a, b) also supports the hypothesis that $\mathrm{P}$ is more rapidly mineralized from dead material than C. Indeed, if POC and PartP are representative of $\mathrm{C}$ and $\mathrm{P}$ living biomass, then the $\mathrm{C}$ to $\mathrm{P}$ incorporation rate ratio should be in the same range as the POC to PartP ratio. The regression slope between POC and PartP concentration was 3489 (Fig. 4a) and 57 between $\mathrm{V}_{\text {DIC }}$ and $\mathrm{V}_{\text {DIP }}$ (Fig. 4b). This difference can be explained by the longer turnover rates of POC than those of PartP.
3.3 Evaluation of the use of $\mathrm{V}_{\mathrm{DIP}}^{\mathrm{sp}}$ as an estimator of bacteria and phytoplankton growth rates

We compared euphotic-layer averaged values of $\mathrm{V}^{\mathrm{sp}}$ obtained from different methods (Fig. 5). For bacteria, we compared the values of $\mathrm{V}_{\mathrm{DIP}}^{\mathrm{sp}}<0.6$ and of HBP:HBB (Fig. 5a). $\mathrm{V}_{\mathrm{DIP}}^{\mathrm{sp}}<0.6$ values were 1.2 to 9.5 times higher than HBP:HBB values in productive areas (MAR-STB6 and STB15-UPX, respectively) while in the centre of the gyre (STB7-STB14), $\mathrm{V}_{\mathrm{DIP}}^{\mathrm{sp}}<0.6$ values were 1.2 to 2.2 times lower than HBP:HBB values. Between MAR and STA21 stations, HBP:HBB values were quite low and constant $\left(0.11 \pm 0.04 \mathrm{~d}^{-1}\right)$ while $\mathrm{V}_{\mathrm{DIP}}^{\mathrm{sp}}<0.6$ values varied widely from 0.04 to $1.11 \mathrm{~d}^{-1}$ depending the trophic regime encountered. As a consequence, the correlation between HBP:HBB ratio and $\mathrm{V}_{\mathrm{DIP}}^{\mathrm{sp}}<0.6$ values, even excluding the "original" upwelling sites, was not significant $\left(\mathrm{r}^{2}=0.08, \mathrm{p}>0.05\right)$. For phytoplankton, we compared the values of $\mathrm{V}_{\mathrm{DIC}>0.6}^{\mathrm{sp}}$ and of $\mathrm{V}_{\mathrm{DIP}>0.6}^{\mathrm{sp}} . \mathrm{V}_{\mathrm{DIC}>0.6}^{\mathrm{sp}}$ can be obtained using a Chla-to-biomass or cell-number-to-biomass conversion factor. Using cell-number-to-biomass conversion factors according to Campbell et al. $(1994,1997)$ we found 


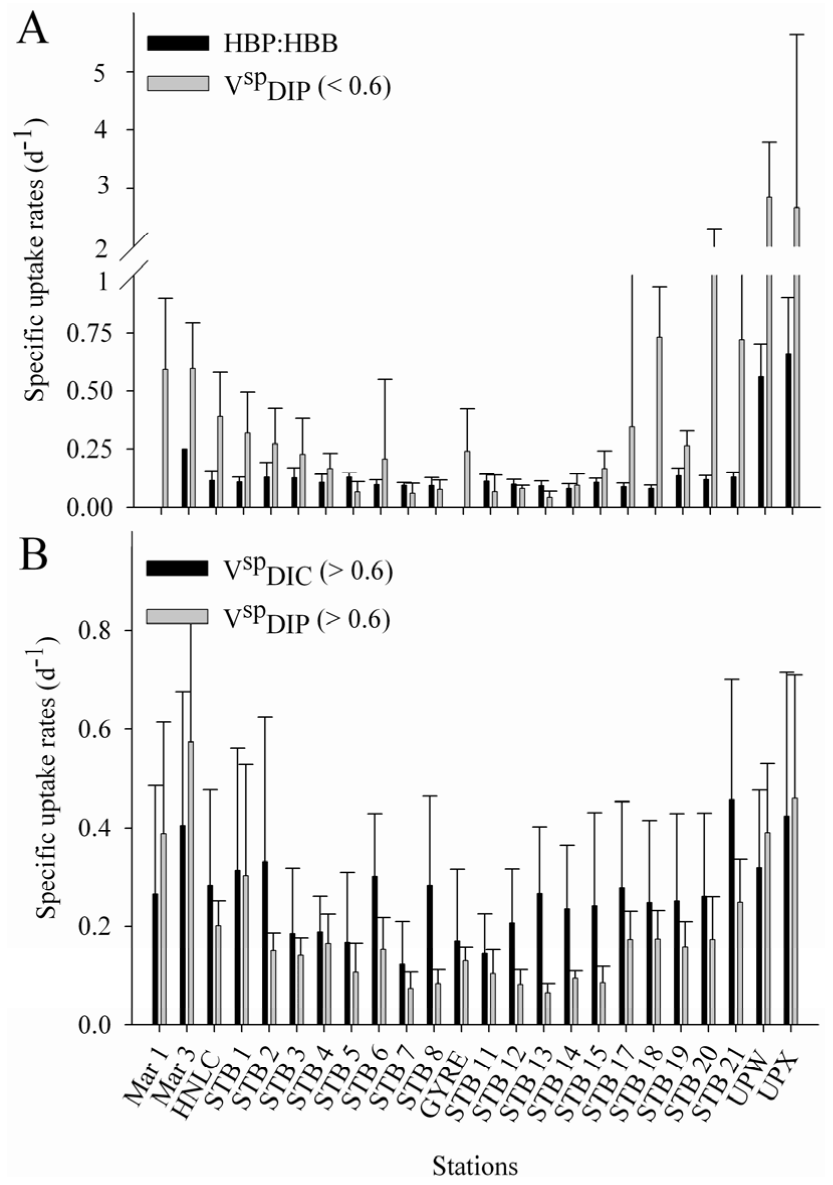

Fig. 5. (A) Bacterial specific uptake rates calculated from HBP:HBB ratio and $V_{\text {DIP }}^{\text {sp }}$ in the fraction $<0.6 \mu \mathrm{m}$. (B) Phytoplankton specific uptake rates calculates from $\mathrm{V}_{\text {DIC }}^{\mathrm{sp}}$ and $\mathrm{V}_{\mathrm{DIP}}^{\mathrm{sp}}$ in the fraction $>0.6 \mu \mathrm{m}$. Average specific uptake rates values on the photic zone. Autotrophic biomass calculated from Chla using a $\mathrm{C}$ :Chla conversion factors as describe in the Materials and Methods section. Heterotrophic bacterial biomass calculated from bacterial cells abundance converted to $\mathrm{C}$ equivalent using a conversion factor of $10 \mathrm{fgC}_{\text {cell }}{ }^{-1}$.

$\mathrm{V}_{\mathrm{DIC}}^{\mathrm{sp}}$ values on average 2 and 12 times higher than using a Chla-to-biomass conversion factors. Greatest differences were found in meso- and eutrophic areas. Using the Chla-tobiomass conversion factors from Veldhuis and Kraay (2004), $\mathrm{V}_{\mathrm{DIC}>0.6}^{\mathrm{sp}}$ values were 1 to 4 and 0.6 to 1.8 times higher than $\mathrm{V}_{\mathrm{DIP}>0.6}^{\mathrm{sp}}$ in the gyre and in the meso- and eutrophic areas, respectively (Fig. 5b). The major bias linked with the determination of $\mathrm{V}_{\mathrm{DIC}}^{\mathrm{sp}}$ is the choice of conversion factor. Indeed, when considering the extreme values of the C:Chla ratio in the surface layer in the equatorial Pacific ocean (40 and $200 \mathrm{~g} \mathrm{C} \mathrm{Chla}^{-1}$, Chavez et al., 1996), values of $\mathrm{V}_{\text {DIC }}^{\mathrm{sp}}$ can vary up to a factor 5 . In the same way, we calculated $\mathrm{V}_{\text {DIC }}^{\mathrm{sp}}$ using different cell-number-to-biomass conversion factors. Using conversion factors provided by Campbell et al. (1997) or by
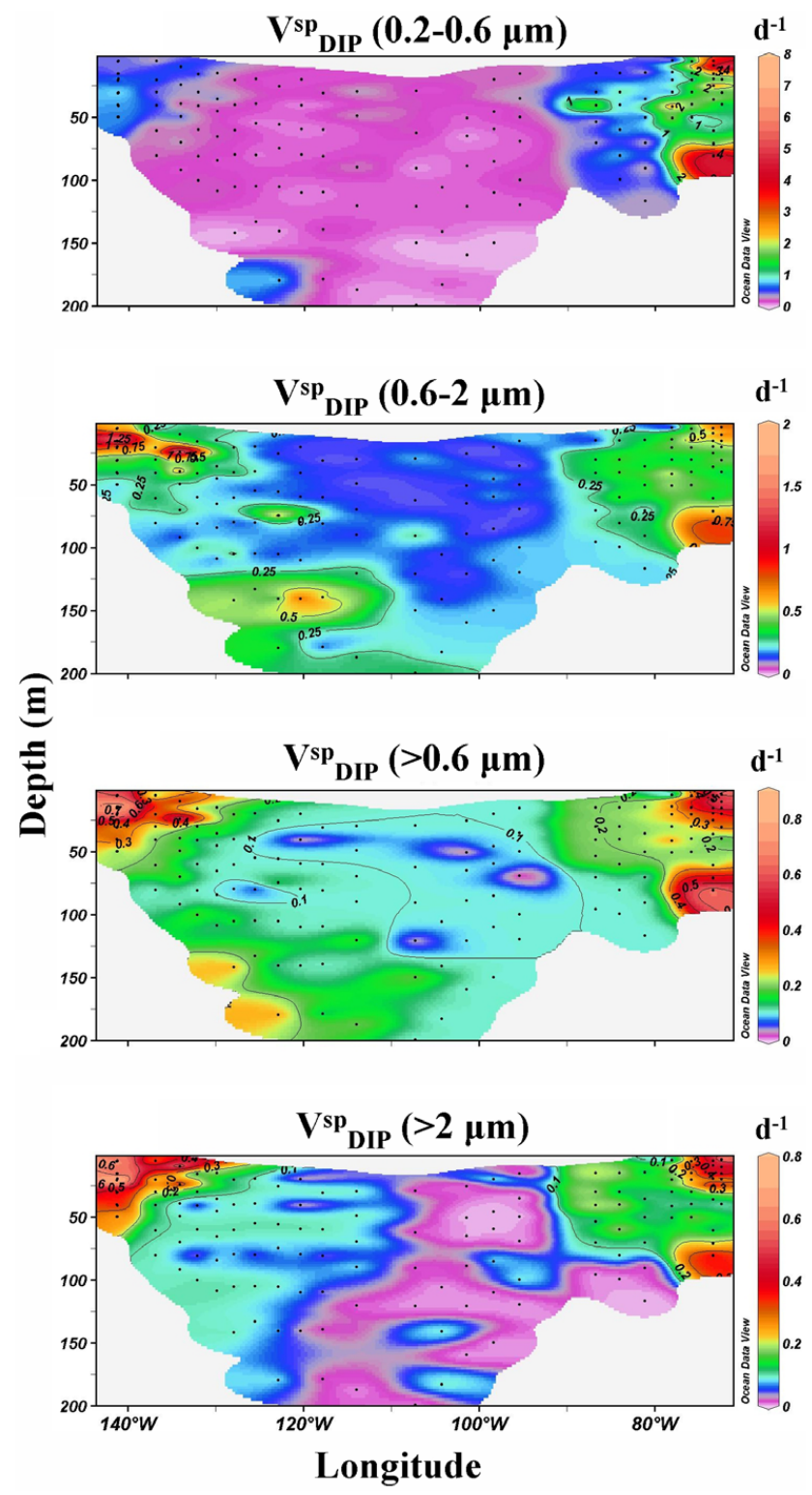

Fig. 6. Vertical and longitudinal distribution of the daily specific uptake of DIP $\left(\mathrm{V}_{\mathrm{DIP}}^{\mathrm{sp}}\right)$ along the BIOSOPE transect for four size classes: $0.2-0.6 ; 0.6-2 ;>0.6$ and $>2 \mu \mathrm{m}$.

Bertilsson et al. (2003) for Prochlorococcus, Synechococcus and picoeucaryotes (see Table 1), we found that $\mathrm{V}_{\mathrm{DIC}}^{\mathrm{sp}}$ values were on average 20\% higher using Campbell's value.

3.4 Estimates of bacteria and phytoplankton $\mathrm{V}_{\mathrm{DIP}}^{\mathrm{sp}}$ in the Southeast Pacific gyre

The different size fractions showed significant vertical and longitudinal variations of $\mathrm{V}_{\mathrm{DIP}}^{\mathrm{sp}}$ along the transect $(\mathrm{P}<0.001$; Fig. 6). Highest values were found in productive areas while lower values were found in the upper part of the photic zone in the gyre area. In productive areas, the $0.2-0.6 \mu \mathrm{m}$ fraction, 
assumed to be composed mostly of free-living heterotrophic bacteria, showed the highest euphotic zone mean values of $\mathrm{V}_{\mathrm{DIP}}^{\mathrm{sp}}\left(0.6 \pm 0.3\right.$ to $\left.3 \pm 1 \mathrm{~d}^{-1}\right)$ while in the gyre area, the 0.6-2 $\mu \mathrm{m}$ fraction, assumed to consist of picophytoplankton cells, showed the highest euphotic zone mean values of $\mathrm{V}_{\mathrm{DIP}}^{\mathrm{sp}}\left(0.10 \pm 0.04\right.$ to $\left.0.20 \pm 0.11 \mathrm{~d}^{-1}\right)$. Whatever the station, the $>2 \mu \mathrm{m}$ fraction had the lowest $\mathrm{V}_{\mathrm{DIP}}^{\mathrm{sp}}$ euphotic zone mean values $\left(0.02 \pm 0.07-0.6 \pm 0.2 \mathrm{~d}^{-1}\right)$. The variation of $\mathrm{V}_{\mathrm{DIP}}^{\mathrm{sp}}$ with depth in the $0.6-2 \mu \mathrm{m}$ fraction was quite different from that of the $>2 \mu \mathrm{m}$ fraction, particularly in the western part of the gyre area. Here, the $>2 \mu \mathrm{m}$ fraction showed fairly constant $V_{\text {DIP }}^{\text {sp }}$ values with depth (no significant difference was found between $\mathrm{V}_{\mathrm{DIP}}^{\mathrm{sp}}$ values in the deep chlorophyll maximum layer (DCML) and the upper layer of the euphotic zone, $\mathrm{P}=0.161$ ), while the $0.6-2 \mu \mathrm{m}$ fraction exhibited significantly higher values of $\mathrm{V}_{\mathrm{DIP}}^{\mathrm{sp}}$ in the DCML $(\mathrm{P}<0.001)$. The smaller size fraction $(0.2-0.6 \mu \mathrm{m})$ exhibited quite low values throughout the euphotic zone in the oligotrophic area $\left(0.11 \pm 0.07 \mathrm{~d}^{-1}\right)$ and no significant tendency with depth was observed $(\mathrm{P}<0.001)$.

\section{Discussion}

Quantifying heterotrophic bacteria and phytoplankton $\mu$ in the ocean is vitally important for understanding many oceanographic processes since $\mu$ and mortality of individual populations control the ultimate composition of the assemblage (Banse, 1991). This, in turn, controls a large number of ecosystem properties, such as export of organic matter, nutrient utilization and production patterns. Understanding $\mu$ is critical to our understanding of the biotic responses to environmental forcing. The physiological responses are an integral component in mechanistic models in predicting ecosystem trophodynamics. Nevertheless, studies of heterotrophic bacteria and phytoplankton assemblages are scarce, especially in the Southeast Pacific. We measured DIP uptake rates and PartP concentrations in three size fractions: 0.2-0.6, 0.62 and $>2 \mu \mathrm{m}$ in order to assess in situ specific growth rates of bacteria and two size fractions of phytoplankton. Firstly, we discuss the production and biomass estimators; secondly, we discuss the P-based $\mu$ estimates obtained in the Southeast Pacific.

\subsection{Biomass estimators}

The distribution of phytoplankton is commonly described in terms of Chla (Huot et al., 2007). Because the Chla content varies between species, light and nutrients (Philips et al., 1995; Sciandra et al., 1997; Finkel et al., 2004; Pérez et al., 2006; Moore et al., 2006), it is not an ideal biomass estimator (Breton et al., 2000; Le Floc'h et al., 2002). POC cannot be used directly as it contains a high proportion of detrital matter (Sobczak et al., 2002; Fig. 4a and d). The AB in terms of $\mathrm{C}$ is never directly determined but derived from other variables: Chla, biovolumes or cell numbers which are then transformed using appropriate conversion factors. This entails a critical step in the estimation of $\mathrm{AB}$ : the choice of conversion factor. C:Chla values vary over a wide range even at species level. As an example, in the subtropical Atlantic ocean, Veldhuis and Kraay (2004) found C:Chla ratios ranging from 450 at the surface to $15 \mathrm{gC} \mathrm{gChla}^{-1}$ at $150 \mathrm{~m}$, for Prochlorococcus populations and a C:Chla ratio of 30$80 \mathrm{gC} \mathrm{gChla}^{-1}$ in surface waters for the collective eukaryotic phytoplankton, varying by a factor of 3-7 fold with depth. In most studies however, authors use values ranging between 30 and $55 \mathrm{gC} \mathrm{gChla}^{-1}$ to convert their Chla data into $\mathrm{C}$ biomass (Gasol et al., 1997; Lequéré et al., 2005; Houlbrèque et al., 2006). For phytoplankton, cell-number-to-C conversion factors can also vary significantly even at the species level (Table 1). We found significant differences $(\mathrm{P}<0.001)$ in $\mathrm{V}_{\mathrm{DIC}}^{\mathrm{sp}}$ estimates according to the choice of phytoplankton cell-number-to-C or C:Chla conversion factors. So although the use of a single conversion factor is the rule in field studies, it probably leads to significant errors in biomass estimates. Conversely, using appropriate cell or Chla to carbon conversion factors demands complex data analysis. Studies on heterotrophic bacterial communities have shown that the $\mathrm{C}$ cell content changes in relation to natural conditions and the physiological state of the bacterial assemblages (Table 1). Gundersen et al. (2002) showed that the outcome of HBB assessments is highly dependant on the choice of cell-specific conversion factors. In the same way, La Ferla and Leonardi (2005) demonstrated that the quantification of HBB based solely on abundance must be considered with caution because of the variability in cell volumes and morphotypes. Thus there is great uncertainty surrounding the estimate of C-based phytoplankton and heterotrophic bacterial $\mu$, whatever the choice of biomass estimator.

$\mathrm{P}$ is an essential element required for life, used by all organisms. It is found in a variety of molecules with different cellular roles, ranging from storage of genetic information (nucleic acids: DNA, RNA) and energy (ATP, ADP, AMP) to structural composition (phospholipids). If the contribution of detrital P to PartP standing stocks is small enough, then PartP can be considered to reflect the standing stock of living material. Our results showed that PartP contained less detrital material than the POC (Fig. 4). This was indicated by significantly higher turnover rates of PartP compared to those of POC and a significant correlation between PartP and Chla concentrations. Similar observations have shown that $P$ is preferentially released from both dissolved and particulate matter into the water column relative to other elements such as C and N (Menzel and Ryther, 1964; Knauer et al., 1979; Minster and Boulahdid, 1987; Clark et al., 1998, 1999; Loh and Bauer, 2000; Paytan et al., 2003). The use of PartP as a living biomass indicator is particularly well adapted to the open ocean. Indeed, in such areas, low values of detrital P are commonly found $(\sim 1 \%$ in equatorial Pacific Ocean, Faul et al., 2005). Nevertheless, even if the fraction of detrital 
$\mathrm{P}$ is negligible in the whole fraction, the size distribution of detrital $\mathrm{P}$ is not known and can affect the measurement of $\mathrm{V}_{\mathrm{DIP}}^{\mathrm{sp}}$ in each size fraction. It has been shown that as the size of the organic matter decreases, the more refractory it becomes (the size-reactivity continuum hypothesis; Amon and Benner, 1996; Mannino and Harvey, 2000), therefore we can hypothesise that there is also a size-reactivity continuum in detrital matter that engender higher concentrations of detrital matter in the smallest fraction. For this reason, $\mathrm{V}_{\mathrm{DIP}<0.6}^{\mathrm{sp}}$ may be underestimated. The proportion of detrital $\mathrm{P}$ in PartP is high in coastal areas (Faul et al., 2005). Consequently, $\mathrm{V}_{\mathrm{DIP}}^{\mathrm{sp}}$ is more likely to be underestimated in the upwelling area. The other main advantage of using $\mathrm{P}$ instead of Chla is that PartP takes both bacteria and phytoplankton into account. So if it is possible to separate bacterial $\mathrm{P}$ from phytoplankton $\mathrm{P}$ in PartP, then it would be possible to estimate bacterial and phytoplankton $\mathrm{V}_{\mathrm{DIP}}^{\mathrm{sp}}$ in the same sample. Size fractionation was an adequate method for separating heterotrophic bacteria from phytoplankton, in our study, since more than $90 \%$ of bacterial cells passed through the $0.6 \mu \mathrm{m}$-filters. However, an increasing fraction of Prochlorococcus cells passed through when the water became ultraoligotrophic (in the centre of the gyre). Consequently, values of heterotrophic bacteria $\mathrm{V}_{\mathrm{DIP}}^{\mathrm{sp}}$ in the gyre may be biased due to the influence of Prochlorococcus cells. Nevertheless, it was shown that DIC uptake in the $0.2-0.6 \mu \mathrm{m}$ fraction was negligible (data not shown) and therefore the phytoplankton production in this fraction was negligible. Thus, production in terms of $\mathrm{P}$ in the $0.2-0.6 \mu \mathrm{m}$ fraction can be mainly attributed to freeliving heterotrophic bacteria. Therefore, $\mathrm{V}_{\mathrm{DIP}}^{\mathrm{sp}}<0.6$ gives a good representation of bacterial $\mu$. In the $>0.6 \mu \mathrm{m}$ size fractions, the nano and microzooplankton can account for some of the PartP concentration values. Gasol et al. (1997) showed that zooplankton C-biomass (protozooplankton + mesozooplankton) could account for $13-21 \%$ and $15-65 \%$ of the total C-biomass in coastal and open ocean areas, respectively. Consequently, this could be a non negligible source of phytoplankton $\mathrm{V}_{\mathrm{DIP}}^{\mathrm{sp}}$ underestimation, particularly for the $>2 \mu \mathrm{m}$ size fraction.

\subsection{DIP uptake rate measurements}

Assuming that the DIP represents biologically available orthophosphate, we measured $\mathrm{P}$ uptake rates $\left(\mathrm{V}_{\mathrm{DIP}}\right)$ in three size fractions. Daily P uptake rates were calculated by multiplying the hourly rate by 24 . P uptake is generally shown to be constant over $24 \mathrm{~h}$ (Perry and Eppley, 1981, Harrison, 1983; Moutin et al., 2002) but diurnal variations in P uptake have been observed in some studies (Eppley et al., 1971; Harrison et al., 1977; Currie and Kalff, 1984). For the majority of stations, time course experiments for ${ }^{33} \mathrm{P}$ uptake were linear over $24 \mathrm{~h}$, however there were some variations in $\mathrm{P}$ uptake rates at some stations along the BIOSOPE transect (Duhamel et al., 2006). The methodological problems associated with $24 \mathrm{~h}$ incubation experiments can be significant
(Nalewajko and Garside, 1983, Harrison and Harris, 1986), especially in terms of losses. However, short incubation experiments should reduce the bias linked to such losses (see discussion in Duhamel et al., 2006). It is important to stress that even if the $<0.6 \mu \mathrm{m}$ fraction is composed of solely heterotrophic bacteria, our data set does not prove that $\mathrm{P}$ is turning over at the same rate as the cells. Indeed, Nalewajko and Lean (1978) measured net phosphate uptake and influx rates in batch cultures of three algal cell cultures. They showed that short-term $P$ fluxes always exceeded the net increase in $P$ biomass, indicating that the cells release $\mathrm{P}$ compounds back into the medium. To the best of our knowledge, the study of Nalewajko and Lean (1978) has not been repeated, so this experiment should be repeated in a variety of field samples to verify that this phenomenon is not exclusively observed in cultures. C-based $\mu$ estimations are also submitted to such error type. Indeed, the release of assimilation products is common to C measurements. Claustre et al. (2007) propose that the release of DOC in the Southeast Pacific should be a major process which could explain the high community (bacteria + phytoplankton) production rates. The release of DOC by phytoplankton cells produces bias in the evaluation of $\mathrm{C}$ production (Wood et al., 1992) and subsequently for C-based $\mu$ estimations.

\subsection{Growth rates estimates}

In 1981, Perry and Eppley used the ${ }^{33} \mathrm{P}$ uptake rate to PartP ratio to estimate the growth rate of phytoplankton (Table 2), stating that DIP assimilation was mediated by phytoplankton (their data indicating low heterotrophic activity). In 1996, Thingstad et al. determined both heterotrophic bacteria and phytoplankton P-based generation times [(PartP $\times{ }^{32} \mathrm{P}$ uptake rate) $\times \ln (2)]$ using $1 \mu \mathrm{m}$ size fractionations (Table 2). From these different studies, where the proportion of detrital matter in the PartP was negligible, it was possible to put forward the hypothesis that DIP was the sole source of $\mathrm{P}$ and so $\mathrm{V}_{\mathrm{DIP}}^{\mathrm{sp}}$ estimates could be used to assess bacteria and/or phytoplankton $\mu$. Thus the idea of using P-based estimates of $\mu$ is not new. In this study we provide information on the variations in Pbased $\mu$ values in a gradient of oligotrophy where the waters where P-repleted (DIP concentration and turnover time minimum values: $120 \mathrm{nmol}^{-1}$ and $7 \mathrm{~d}^{-1}$, respectively; Moutin et al., 2007). Most estimates for C-based heterotrophic bacterial growth rates in the open ocean fall into a wide range from zero to $10 \mathrm{~d}^{-1}$, whilst phytoplankton appears to grow at rates of no more than $2 \mathrm{~d}^{-1}$ (Table 2). We report a wide range in $\mu$ estimates ranging from 0 to $7 \mathrm{~d}^{-1}$ for heterotrophic bacteria and from 0 to $2 \mathrm{~d}^{-1}$ for phytoplankton. This range of values reflects the wide range of trophic status encountered during the BIOSOPE cruise.

Estimates of production to biomass ratio, based on the leucine incorporation technique and $\mathrm{C}$ conversion of bacterial abundance (HBP:HBB) were significantly lower than those estimated by $\mathrm{V}_{\mathrm{DIP}}^{\mathrm{sp}}<0.6$ in productive areas 
Table 2. Review of values of surface water phytoplankton and bacteria growth rate $\left(\mathrm{d}^{-1}\right)$.

\begin{tabular}{|c|c|c|c|}
\hline Growth rate $\left(d^{-1}\right)$ & Technique & Organisms - location & Reference \\
\hline $0.76(0.57-1.07)$ & Dilution technique & Phytoplankton - North-east Atlantic & Quevedo and Anadon 2001 \\
\hline $0.26(0.19-0.36)$ & ${ }^{14} \mathrm{C}$ method & Phytoplankton - eastern North Atlantic subtropical gyre & Maranon, 2005 \\
\hline $0.51(0.42-0.62)$ & ${ }^{14} \mathrm{C}$ method & Phytoplankton - western North Atlantic subtropical gyre & Maranon, 2005 \\
\hline $0.17(0.13-0.22)$ & ${ }^{14} \mathrm{C}$ method & Phytoplankton - South Atlantic subtropical gyre & Maranon, 2005 \\
\hline $0.21 \pm 0.02$ & ${ }^{14} \mathrm{C}$ method & Microphytoplankton - oligotrophic area - Atlantic ocean & Maranon et al., 2000 \\
\hline $0.1->1.5$ & Review & Phytoplankton - poor water of the open ocean & Eppley, 1981 \\
\hline $0.0-2.9$ & Review & Phytoplankton assemblages & Furnas, 1990 \\
\hline $0.3-0.53$ & ${ }^{14} \mathrm{C}$ method & Phytoplankton - Station ALOHA - $22^{\circ} 45^{\prime} \mathrm{N} ; 158^{\circ} 00^{\prime} \mathrm{W}$ & Letelier et al., 1996 \\
\hline 1 & Pigment labeling with ${ }^{14} \mathrm{C}$ & Phytoplankton - North Pacific subtropical gyre & Laws et al., 1987 \\
\hline $0.3-0.6$ & Pigment labeling with ${ }^{14} \mathrm{C}$ & Cyanobacteria - Sargasso Sea off Bermuda & Goericke 1998 \\
\hline 0.14 & Specific DIP uptake rate & Phytoplankton - Central North pacific Ocean & Perry and Eppley, 1981 \\
\hline $3.5-8.8 \mathrm{~d}$ & P-based generation time & Phytoplankton (>1 $\mu \mathrm{m})-$ Bay of Aarhus (Denmark) & Thingstad et al., 1996 \\
\hline $0.06-0.99$ & Specific DIP uptake rate & Picophytoplankton $(0.6-2 \mu \mathrm{m})$ - Southeast Pacific $146.36^{\circ} \mathrm{W}, 72.49^{\circ} \mathrm{W}$ & This study \\
\hline $0.02-0.83$ & Specific DIP uptake rate & Nano-microphytoplankton $(>2 \mu \mathrm{m})$ - Southeast Pacific $146.36^{\circ} \mathrm{W}, 72.49^{\circ} \mathrm{W}$ & This study \\
\hline 1.44 & Seawater culture & Bacteria - North western Atlantic Ocean & Ducklow and Hill, 1985 \\
\hline $0-0.45$ & Dilution technique & Bacteria - Gulf of Mexico & Jochem et al., 2004 \\
\hline $2-10$ & Review & Bacteria & Ducklow, 1983 \\
\hline 4.7 & ${ }^{3} \mathrm{H}$-adenine method & Bacteria - North pacific subtropical gyre & Jones et al., 1996 \\
\hline $0.2-1.5$ & ${ }^{3} \mathrm{H}$-Thymidine method & Bacteria - western Black Sea & Morgan et al., 2006 \\
\hline $0.03-1.1$ & ${ }^{3} \mathrm{H}$-Thymidine method & Bacteria - Danube - Black Sea & Becquevort et al., 2002 \\
\hline $0.004-0.25$ & ${ }^{3} \mathrm{H}-$ Leucine method & Bacteria - review & Van Wambeke et al., 2007 \\
\hline $0.31 \pm 0.09$ & ${ }^{3}$ H-Leucine method & Bacteria - Northeast Pacific Ocean $44^{\circ} 38.3^{\prime} \mathrm{N}, 124^{\circ} 18.5^{\prime} \mathrm{W}$ & Sherr et al., 2001 \\
\hline $0.03 \pm 0.01$ & ${ }^{3}$ H-Leucine method & Bacteria - Northeast Pacific Ocean $44^{\circ} 38.3^{\prime} \mathrm{N}, 124^{\circ} 48.0^{\prime} \mathrm{W}$ & Sherr et al., 2001 \\
\hline $0.02 \pm 0.01$ & ${ }^{3}$ H-Leucine method & Bacteria - Northeast Pacific Ocean $44^{\circ} 38.65^{\prime} \mathrm{N}, 127^{\circ} 10^{\prime} \mathrm{W}$ & Sherr et al., 2001 \\
\hline $0.1-0.45$ & ${ }^{3}$ H-Leucine method & Bacteria - eastern equatorial Pacific Ocean $4.6^{\circ} \mathrm{S}, 105^{\circ} \mathrm{W}$ & Cochlan, 2001 \\
\hline $2.5-4.1$ & P-based generation time & Bacteria $(0.2-1 \mu \mathrm{m})-$ Bay of Aarhus (Denmark) & Thingstad et al., 1996 \\
\hline $0.06-4.28$ & Specific DIP uptake rate & Bacteria $(0.2-0.6 \mu \mathrm{m})-$ Southeast Pacific $146.36^{\circ} \mathrm{W}, 72.49^{\circ} \mathrm{W}$ & This study \\
\hline
\end{tabular}

(MAR-STB6 and STB15-UPX, P<0.001). Applying various methods (measurements of the natural abundance of nucleoid-containing cells by combined epifluorescence and phase-contrast microscopy; detection of the reduction of the fluorogenic dye, 5-cyano-2,3-ditolyl tetrazolium chloride; nucleic acid double staining (SYBR Green + propidium iodide); determination of membrane integrity by confocal laser-scanning microscopy), it has been shown that at any given time, a significant fraction of the bacterioplankton community has minimal or no metabolic activity (Zweifel and Hagström, 1995; Sherr et al., 1999; Gregori et al., 2001; Pirker et al., 2005). For this reason, $\mu$ estimates based on the HBP:HBB ratio could be underestimated. Our $\mathrm{V}_{\mathrm{DIP}<0.6}^{\mathrm{sp}}$ values were significantly higher in the productive areas than in the gyre area $(\mathrm{P}<0.001)$. Morgan et al. (2006) also found that bacterial growth rates (with $\mu=\mathrm{HBP} /$ bacterial abundance, HBP deduced from ${ }^{3} \mathrm{H}$-Thymidine method using conversion factor of $2 \times 10^{18}$ cells $\times[\mathrm{mol} \mathrm{TdR}]^{-1}$ ) were significantly greater on the shelf $\left(0.8-1.8 \mathrm{~d}^{-1}\right)$ compared to the gyre $\left(0.1-0.3 \mathrm{~d}^{-1}\right)$ in the western Black Sea.

Studies comparing bacterial and phytoplankton $\mu$ are few (Jones et al., 1996; Almeida et al., 2002). Measurements of $\mathrm{V}_{\mathrm{DIP}}^{\mathrm{sp}}$ in the $0.2-0.6,0.6-2$ and $>2 \mu \mathrm{m}$ fractions have enabled us to make such comparisons. In oligotrophic environments, heterotrophic bacterial $\mu$ can be higher or lower than that of phytoplankton. For example, Pérez et al. (2006) showed that in the upper water (mixed layer) of the subtropical Atlantic gyres, phytoplankton growth rates were $0.17 \mathrm{~d}^{-1}$ (from daily AP and picoplankton abundance transformed to B with the empirical conversion factors obtained by Zubkov et al. (2000), see Table 1). While in the same area, Zubkov et al. (2000) found that heterotrophic bacterial growth rates were $0.12 \mathrm{~d}^{-1}$ (using a conversion factor of $11.5 \mathrm{fg} \mathrm{C}$ per heterotrophic bacteria). In the upper $40 \mathrm{~m}$ of the North Pacific subtropical gyre, Jones et al. (1996) found $0.7 \mathrm{~d}^{-1}$ for phytoplankton (estimated from the Chlalabelling technique) and $\sim 1 \mathrm{~d}^{-1}$ for heterotrophic bacteria (estimated from the incorporation of ${ }^{3} \mathrm{H}$-adenine into DNA). We showed that picophytoplankton $\mu\left(0.14 \pm 0.04 \mathrm{~d}^{-1}\right)$ was higher than heterotrophic bacteria $\mu\left(0.11 \pm 0.07 \mathrm{~d}^{-1}\right)$ in the Southeast Pacific gyre and that values were in the same range as those found by Pérez et al. (2006) and Zubkov et al. (2000) in the Atlantic gyres, suggesting the presence of a microbial community with a very slow turnover. These relatively low values of $\mu$ for both phytoplankton and heterotrophic bacteria in the oligotrophic gyre area must be the result of nitrogen limitation on bacterial and primary production (Bonnet et al., 2007; Van Wambeke et al., 2007a). Slow phytoplankton $\mu$ in the subtropical Atlantic have been explained in terms of the observed assimilation numbers and C:Chla ratios in a review by Marañon (2005). The light-saturated, chlorophyll normalised photosynthesis rate 
necessary to support a phytoplankton $\mu$ of $1 \mathrm{~d}^{-1}$, would be well above those reported in the subtropical Atlantic $\left(156 \pm 16\right.$ and $205 \pm 17 \mathrm{mg} \mathrm{C} \mathrm{m}^{-2} \mathrm{~d}^{-1}$, in the North and South Atlantic subtropical gyres, respectively; Pérez et al., 2006) and the Southeast Pacific gyre $\left(134 \pm 82 \mathrm{mg} \mathrm{C} \mathrm{m}^{-2} \mathrm{~d}^{-1}\right.$; Van Wambeke et al., 2007b). In coastal areas heterotrophic bacterial $\mu$ are often lower than that of phytoplankton (Laws et al., 1984; Revilla et al., 2000). In the productive areas (MAR-STB6 and STB15-UPX) of the Southeast Pacific, we found that organisms in the $<0.6 \mu \mathrm{m}$ fraction had higher $\mathrm{V}_{\mathrm{DIP}}^{\mathrm{sp}}$ values than organisms in the $>0.6$ fraction, while in the hyperoligotrophic gyre, organisms in the $0.6-2 \mu \mathrm{m}$ fraction yielded the highest $\mathrm{V}_{\mathrm{DIP}}^{\mathrm{sp}}$ values. Thus it may be deduced that the picophytoplankton were better adapted than the nano-microphytoplankton and free living heterotrophic bacteria for growing in hyperoligotrophic conditions.

There are relatively few studies comparing $\mu$ for different size fractions of natural phytoplanktonic communities (Pérez et al., 2006). In coastal eutrophic ecosystems, large phytoplankton are reported to have faster growth rates than small-sized phytoplankton (Cermeno et al., 2005 - C-specific photosynthetic rates). Nevertheless, in the Chilean upwelling area, there was no significant difference between $\mathrm{V}_{\mathrm{DIP}}^{\mathrm{sp}}$ for the two size-fractions of phytoplankton $\left(0.5 \pm 0.3\right.$ and $0.4 \pm 0.2 \mathrm{~d}^{-1}$ for picophytoplankton and nanomicrophytoplankton respectively, $\mathrm{P}>0.05)$. We found that picophytoplankton $(0.6-2 \mu \mathrm{m})$ grew 1 to 15 times faster than the nano-microphytoplankton $(>2 \mu \mathrm{m})$ between the Marquesas Islands and Chile, with maximal differences in the gyre area. Differences in growth rates have been related to the specific composition of the planktonic community (Furnas, 1990). So the differences we observed could be related to differences between the taxonomic groups encountered along the BIOSOPE transect. Flow cytometry data showed high variations in the relative composition of picophytoplankton populations along the BIOSOPE transect (Grob et al., 2007). In the hyperoligotrophic region, the DCM corresponded to Prochlorococcus and picophytoeukaryotes maxima (Grob et al., 2007) as well as to the maximum growth rate values of the picophytoplankton size fraction (Fig. 6).

In most of the oligotrophic area, phytoplankton $\mu$ were found to be higher in the upper mixed layer than within the DCML (Malone et al., 1993 - with AP deduced from the ${ }^{14} \mathrm{C}$ labelling method and $\mathrm{AB}$ deduced using a $\mathrm{C}$ :Chla ratio or ${ }^{14} \mathrm{C}$-Chla experiments ; Quevedo and Anadon, 2001 - dilution method). We found that picophytoplankton grew significantly faster at the DCML than in the upper part of the photic zone in the hyperoligotrophic gyre (from STB7 to STB14; $\mathrm{P}<0.001$ ). Pérez et al. (2006) found the same trends in the subtropical Atlantic gyres with a $\mu$ in the $<2 \mu \mathrm{m}$ fraction of, $0.17 \pm 0.01 \mathrm{~d}^{-1}$ in the mixed layer and $0.25 \pm 0.02 \mathrm{~d}^{-1}$ in the DCML. However, they found that the large size fraction $(>2 \mu \mathrm{m})$ grew faster in the mixed layer than in the DCML while we found no statistical difference for $\mathrm{V}_{\mathrm{DIP}}^{\mathrm{sp}}>2$
$(\mathrm{P}=0.161)$. Our results support the hypothesis of Pérez et al. (2006) that picoplankton could outcompete large cells in the high-nutrient, low-light environment of the DCML.

The evaluation of $\mu$ is still a subject of debate (Marañon, 2005). It is not possible to judge which technique is best for measuring $\mu$, if indeed any one technique is capable of doing so, as each method measures a different aspect of growth. Pbased $\mu$ estimates are one of the many ways to assess $\mu$ and by comparing the results obtained with those of the different existing methods can help to understand how quickly the cells grow in relation to their environment (Christian et al., 1982; Laws et al., 1984; Jespersen et al., 1992).

\section{Conclusions}

Growth rate is a fundamental property of all organisms and gives valuable information about the activity of microbial populations. The relative activity of bacteria and phytoplankton in oligotrophic oceans has significant implications for food-web structures, nutrient cycling pathways and for sinking fluxes of organic matter. Contrary to C-based approaches, the P-based approach enables us to assess bacterial and phytoplankton $\mu$ on the same sample in that size fraction can effectively isolate both heterotrophic and phytoplanktonic communities. We have characterized the vertical and longitudinal variability of P-based $\mu$ in three size fractions of plankton. Picophytoplankton $(0.6-2 \mu \mathrm{m})$ grew faster than the large phytoplankton $(>2 \mu \mathrm{m})$ over the Southeast Pacific transect, particularly in the centre of the gyre. Thus, cells smaller than $2 \mu \mathrm{m}$ were better adapted for growing in a wide range of trophic conditions than those greater than $2 \mu \mathrm{m}$. Heterotrophic bacteria $(0.2-0.6 \mu \mathrm{m})$ showed higher variations in P-based $\mu$ with maximum rates in productive areas. Picophytoplankton grew faster than heterotrophic bacteria in the Southeast Pacific gyre with values in the range of those found in the Atlantic and North pacific gyres by Pérez et al. (2006) and Zubkov et al. (2000), suggesting the presence of a microbial community with a slow turn over.

Acknowledgements. We express our gratitude to O. Ulloa, G. Alarcon and C. Grob for providing us cytometry data. We thank T. Bentley for help with improving the English. We also thank the crew of the R/V L'Atalante for outstanding shipboard support operations. D. Tailliez and C. Bournot are warmly thanked for their efficient help in CTD rosette management and data processing. This is a contribution to the BIOSOPE project of the LEFE-CYBER program. This research was funded by the Centre National de la Recherche Scientifique (CNRS), the Institut des Sciences de l'Univers (INSU), the Centre National d'Etudes Spatiales (CNES), the European Space Agency (ESA), The National Aeronautics and Space Administration (NASA) and the Natural Sciences and Engineering Research Council of Canada (NSERC). This work is funded in part by the French Research and Education council.

Edited by: A. Boetius 


\section{References}

Almeida, M. A., Cunha, M. A., and Alcântara, F.: Seasonal change in the proportion of bacterial and phytoplankton production along a salinity gradient in a shallow estuary, Hydrobiologia, 475-476, 251-262, 2002.

Amon, R. M. W. and Benner, R.: Bacterial utilization of different size classes of dissolved organic matter, Limnol. Oceanogr., 41, 41-51, 1996.

Azam, F., Frenchel, T., Field, J. G., Gray, J. S., Meyer-Reil, L. A., and Thingstad, T. F.: The ecological role of water-column microbes in the sea, Mar. Ecol.-Prog. Ser., 10, 257-263, 1983.

Banse, K.: Rates of phytoplankton cell division in the field and in iron enrichment experiments, Limnol. Oceanogr., 36, 18861898, 1991.

Banse, K.: Should we continue to measure 14C-uptake by phytoplankton for another 50 years?, Limnology and Oceanography: Bulletin, 11, 45-46, 2002.

Becquevort, S., Bouvier, T., Lancelot, C., Cauwet, G., Deliat, G., Egorov, V. N., and Popovichev, V. N.: The seasonal modulation of organic matter utilization by bacteria in the Danube-Black Sea mixing zone, Estuar. Coast. Shelf S., 54, 337-354, 2002.

Berman, T.: Multiple isotopic tracer methods in the study of growth, dynamics and metabolic processes in marine ecosystems, in: Primary Productivity in the Sea, edited by: Falkowski, P., Plenum Publishing, 213-229, 1980.

Bertilsson, S., Berglund, O., Karl, D. M., and Chisholm, S. W.: Elemental composition of marine Prochlorococcus and Synechococcus: Implications for the ecological stoichiometry of the sea, Limnol. Oceanogr., 48, 1721-1731, 2003.

Bonnet, S., Guieu, C., Bruyant, F., Prasil, O., Raimbault, P., Max Y. Gorbunov, M., Zehr, J. P., Grob, C., Masquelier, S., Garczareck, L., Moutin, T., Van Wambeke, F., and Claustre, H.: Nutrients limitation of primary productivity in the Southeast Pacific (BIOSOPE cruise), Biogeosciences Discuss., 4, 2733-2759, 2007 , http://www.biogeosciences-discuss.net/4/2733/2007/.

Breton, E., Brunet, C., Sautour, B., and Brylinski, J. M.: Annual variations of phytoplankton biomass in the Eastern English Channel: comparison by pigment signatures and microscopic counts, J. Plankton Res., 22, 1423-1440, 2000.

Brock, T. D.: Microbial growth rates in nature, Bacteriol. Rev., 35, 39-58, 1971.

Cailliau, C., Claustre, H., Vidussi, F., Marie, D., and Vaulot, D.: Carbon biomass and gross growth rates as estimated from 14C pigment labelling method during photoacclimation in Prochlorococcus CCMP1378), Mar. Ecol.-Prog. Ser., 145, 209-221, 1996.

Campbell, L., Liu, H., Nolla, H. A., and Vaulot, D.: Annual variability of phytoplankton and bacteria in the subtropical North Pacific Ocean at Station ALOHA during the 1991-1994 ENSO event, Deep-Sea Res. Pt. I, 44, 167-192, 1997.

Campbell, L., Nolla, H. A., and Vaulot, D.: The importance of Prochlorococcus to community structure in the central North Pacific Ocean, Limnol. Oceanogr., 39, 954-961, 1994.

Caron, D. A., Dam, H. G., Kremer, P., Lessard, E. J., Madin, L. P., Malone, T. C., Napp, J. M., Peele, E. R., Roman, M. R., and Youngbluth, M. J.: The contribution of microorganisms to particulate carbon and nitrogen in surface waters of the Sargasso Sea near Bermuda, Deep-Sea Res. Pt. I, 42, 943-972, 1995.

Cermeno, P., Maranon, E., Rodriguez, J., and Fernandez, E.: Large- sized phytoplankton sustain higher carbon-specific photosynthesis than smaller cells in a coastal eutrophic ecosystem, Mar. Ecol.-Prog. Ser., 297, 51-60, 2005.

Chavez, F. P., Buck, K. R., Service, S. K., Newton, J., and Barber, R. T.: Phytoplankton variability in the central and eastern tropical Pacific, Deep-Sea Res. Pt. II, 43, 835-870, 1996.

Christian, J. R. and Karl, D. M.: Microbial community structure at the U.S. -Joint Global Ocean flux Study Station ALOHA: Inverse methods for estimating biochemical indicator ratios, J. Geophys. Res., 99, 14 269-14 276, 10.1029/94JC00681, 1994.

Christian, R. R., Hanson, R. B., and Newell, S. Y.: Comparison of methods for measurement of bacterial growth rates in mixed batch cultures, Appl. Environ. Microb., 43, 1160-1165, 1982.

Clark, L. L., Ingall, E. D., and Benner, R.: Marine organic phosphorus cycling: Novel insights from nuclear magnetic resonance, Am. J. Sci., 2999, 724-737, 1999.

Clark, L. L., Ingall, E. D., and Benner, R.: Marine phosphorus is selectively remineralized, Nature, 393, 426, 1998.

Claustre, H. and Maritorena, S.: The Many Shades of Ocean Blue, Science, 302, 1514-1515, 2003.

Claustre, H., Bricaud, A., Babin, M., Bruyant, F., Guillou, L., Le Gall, F., and Partensky, F.: Diel variations in Prochlorococcus optical properties, Limnol. Oceanogr., 47, 1637-1647, 2002.

Cochlan, W.: The heterotrophic bacterial response during a mesoscale iron enrichment experiment (IronEx II) in the eastern equatorial Pacific Ocean. Limnology and Oceanography, 46, 428-435, 2001.

Currie, D. J. and Kalff, J.: The relative importance of bacterioplankton and phytoplankton in phosphorus uptake in freshwater, Limnol. Oceanogr., 29, 311-321, 1984.

Dickson, M.-L. and Wheeler, P. A.: Nitrate uptake rates in a coastal upwelling regime: A comparison of $\mathrm{PN}$-specific, absolute, and Chl a-specific rates. Limnology and Oceanography, 40, 533-543, 1995.

Ducklow, H. W.: Bacterial production and biomass in the oceans, in: Microbial ecology of the oceans, edited by: Kirchman, D. L., Wiley series in Ecological and Applied Microbiology, Ralph Mitchekk, Series Editor., 85-120, 2000.

Ducklow, H. W.: Production and fate of bacteria in the oceans, Bioscience, 33, 494-501, 1983.

Duhamel, S., Zeman, F., and Moutin, T.: A dual-labeling method for the simultaneous measurement of dissolved inorganic carbon and phosphate uptake by marine planktonic species, Limnol. Oceanogr.-Meth., 4, 416-425, 2006.

Eppley, R. W., Carlucci, A. F., Holm-Hansen, Kiefer, D., McCarthy, J. J., Venrick, E., and Williams, P. M.: phytoplankton growth and composition in shipboard cultures supplied with nitrate, ammonium, or urea as the nitrogen source, Limnol. Oceanogr., 16, 741-751, 1971.

Eppley, R. W.: Relations between nutrient assimilation and growth rate in phytoplankton with a brief review of estimates of growth rate in the ocean. in: Physiological Bases of Phytoplankton Ecology, edited by: Platt, T., Can. Bull. Fish. Aquat. Sci., 210, 251263, 1981.

Eppley, R. W.: Temperature and phytoplankton growth in the sea, Fish. B.-N.O.A.A., 70, 1063-1085, 1972.

Faul, K. L., Paytan, A., and Delaney, M. L.: Phosphorus disctribution in sinking oceanic particulate matter, Mar. Chem., 97, 307333, 2005. 
Finkel, Z. V., Irwin, A. J., and Schofield, O.: Resource limitation alters the $3 / 4$ size scaling of metabolic rates in phytoplankton, Mar. Ecol.-Prog. Ser., 273, 269-279, 2004.

Fuhrman, J. A. and Azam, F.: Bacterioplankton secondary production estimates for coastal waters of British Colombia, Antarctica and California, Appl. Environ. Microb., 39, 1085-1095, 1980.

Fuhrman, J. A. and Azam, F.: Thymidine incorporation as a measure of heterotrophic bacterioplankton production in marine surface waters: Evaluation and field results, Mar. Biol., 66, 109$120,1982$.

Fukuda, R., Ogawa, H., Nagata, T., and Koike, I.: Direct determination of carbon and nitrogen contents of natural bacterial assemblages in marine environments, Appl. Environ. Microb., 64, 3352-3358, 1998.

Furnas, M. J.: In situ growth rates of marine phytoplankton: approaches to measurement, community and species growth rates, J. Plankton Res., 12, 1117-1151, 1990.

Gasol, J. M., Del Giogio, P., and Duarte, C. M.: Biomass distribution in marine planktonic communities, Limnol. Oceanogr., 42, 1353-1363, 1997.

Goericke, R.: Response of phytoplankton community structure and taxon-specific growth rates to seasonally varying physical forcing in the Sargasso Sea off Bermuda, Limnol. Oceanogr., 43, 921-935, 1998.

Grégori, G., Citterio, S., Ghiani, A., Labra, M., Sgorbati, S., Brown, S., and Denis, M.: Resolution of viable and membranecompromised bacteria in freshwater and marine waters based on analytical flow cytometry and nucleic acid double staining, Appl. Environ. Microb., 67, 4662-4670, 2001.

Grob, C., Ulloa, O., Claustre, H., Huot, Y., Alarcon, G., and Marie, D.: Contribution of picoplankton to the total particulate organic carbon (POC) concentration in the eastern South Pacific, Biogeosciences, 4, 837-852, 2007,

http://www.biogeosciences.net/4/837/2007/.

Gundersen, K., Heldal, M., Norland, S., Purdie, D. A., and Knap, A. H.: Elemental C, N, and P cell content of individual bacteria collected at the Bermuda Atlantic Time-series Study (BATS) site, Limnol. Oceanogr., 47, 1525-1530, 2002.

Hagstrom, A., Larsson, U., Horstedt, P., and Normark, S.: Frequency of dividing cells, a new approach to the determination of bacterial growth rates in aquatic environments, Appl. Environ. Microb., 37, 805-812, 1979.

Harrison, W. G. and Harris, L. R.: Isotope dilution and its effects on measurements of nitrogen and phosphorus by oceanic microplankton, Mar. Ecol.-Prog. Ser., 27, 253-261, 1986.

Harrison, W. G., Azam, F., Renger, E. H., and Eppley, R. W.: Some experiments on phosphate assimilation by coastal marine plankton, Mar. Biol., 40, 9-18, 1977.

Harrison, W. G.: The time-course of uptake of inorganic and organic nitrogen compounds by phytoplankton from the Eastern Canadian Arctic: A comparison with temperate and tropical populations, Limnol. Oceanogr., 28, 1231-1237, 1983.

Herbland, A., Le Bouteiller, A., and Raimbault, P.: Size structure of phytoplankton biomass in the equatorial Atlantic Ocean, DeepSea Res. Pt. I, 32, 819-836, 1985.

Houlbrèque, F., Delesalle, B., Blanchot, J., Montel, Y., and FerrierPagès, C.: Picoplankton removal by the coral reef community of La Prévoyante, Mayotte Island, Aquat. Microb. Ecol., 44, 59-70, 2006.
Huot, Y., Babin, M., Bruyant, F., Grob, C., Twardowski, M. S., Claustre, H.: Relationship between photosynthetic parameters and different proxies of phytoplankton biomass in the subtropical ocean, Biogeosciences, 4, 853-868, 2007, http://www.biogeosciences.net/4/853/2007/.

Jespersen, A.-M., Nielsen, J., Riemann, B., and Sondergaard, M.: Carbon-specific phytoplankton growth rates: a comparison of methods, J. Plankton Res., 14, 637-648, 1992.

Jones, D. R., Karl, D. M., and Laws, E. A.: Growth rates and production of heterotrophic bacteria and phytoplankton in the North Pacific subtropical gyre, Deep-Sea Res. Pt. I, 43, 1567-1580, 1996.

Kirchman, D. L., K'nees, E., and Hodson, R.: Leucine incorporation and its potential as a measure of protein synthesis by bacteria in natural aquatic systems, Appl. Environ. Microb., 49, 599-607, 1985.

Kirchman, D. L.: Calculating microbial growth rates from data on production and standing stocks, Mar. Ecol.-Prog. Ser., 233, 303306, 2002.

Kirchman, D. L.: Leucine incorporation as a measure of biomass production by heterotrophic bacteria, in: Handbook of methods in aquatic microbial ecology, edited by: Kemp, P. F., Sherr, B. F., Sherr, E. B., and Cole, J. J., Boca Raton: Lewis, 509-512, 1993.

Kirkwood, D. S.: Stability of solutions of nutrient salts during storage. Mar. Chem., 38, 151-164, 1992.

Knauer, G. A., Martin, J. H., and Bruland, K. W.: Fluxes of particulate carbon, nitrogen, and phosphorus in the upper water column of the northeast Pacific, Deep-Sea Res., 26, 97-108, 1979.

La Ferla, R. and Leonardi, M.: Ecological implications of biomass and morphotype variations of bacterioplankton: an example in a coastal zone of the Northern Adriatic Sea (Mediterranean), Mar. Ecol., 26, 82-88 doi:10.1111/j.1439-0485.2005.00049.x, 2005.

Landry, M. R. and Hassett, R. P.: Estimating the grazing impact of marine micro-zooplankton, Mar. Biol., 67, 283-288, 1982.

Laws, E. A., Ditullio, G. R., and Redalje, D. G.: High phytoplankton growth and production rates in the North Pacific subtropical gyre, Limnol. Oceanogr., 32, 905-918, 1987.

Laws, E. A., Redalje, D. G., Haas, L. W., Bienfang, P. K., Eppley, R. W., Harrison, W. G., Karl, D. M., and Marra, J.: High phytoplankton growth and production rates in oligotrophic Hawaiian coastal waters, Limnol. Oceanogr., 29, 1161-1169, 1984.

Le Floc'h, E., Gilbert, M., and Antoine, S.: An automatic device for in vivo absorption spectra acquisition and chlorophyll estimation in phytoplankton cultures, J. Appl. Phycol., V14, 435-444, 2002.

Le Quéré, C., Harrison, S., Prentice, I. C., Buitenhuis, E. T., Aumont, O., BOPP, L., Claustre, H., Cotrim Da Cunha, L., Geider, R., Giraud, X., Klass , C., Kohfeld, K. E., Legendre, k. L., Manizza, M., Platt , T., Rivkin , R. B., Sathyendranath, S., Uitz, J., Watson, Y. J., and Wofl - Glaro, D.: Ecosystem dynamics based on plankton functional types for global ocean biogeochemistry models, Glob. Change Biol., 11, 1-25, doi:10.1111/j.13652486.2005.001004.x, 2005.

Lee, S. and Fuhrman, J. A.: Relationships between biovolume and biomass of naturally derived marine bacterioplankton, Appl. Environ. Microb., 53, 1298-1303, 1987.

Letelier, R. M., Dore, J. E., Winn, C. D., and Karl, D. M.: Seasonal and interannual variations in photosynthetic carbon assimilation at Station, Deep-Sea Res. Pt. II, 43, 467-490, 1996.

Lipschultz, F.: Nitrogen-specific uptake rates of marine phytoplank- 
ton isolated from natural populations of particles by flow cytometry, Mar. Ecol.-Prog. Ser., 123, 245-258, 1995.

Liu, H., Landry, M. R., Vaulot, D., and Campbell, L.: Prochlorococcus growth rates in the central equatorial Pacific: An application of the fmax approach J. Geophys. Res., 104, 3391-3399, 1999.

Loh, A. N., Bauer, J. E., and Druffel, E. R. M.: Variable ageing and storage of dissolved organic components in the open ocean, Nature, 430, 877-881, 2004.

Malone, T. C., Pike, S. E., and Conley, D. J.: Transient variations in phytoplankton productivity at the JGOFS Bermuda time series station, Deep-Sea Res. Pt. I,, 40, 903-924, 1993.

Mannino, A. and Harvey, H. R.: Biochemical composition of particles and dissolved organic matter along an estuarine gradient: Sources and implications for DOM reactivity, Limnol. Oceanogr., 45, 775-788, 2000.

Maranon, E., Cermeno, P., and Perez, V.: Continuity in the photosynthetic production of dissolved organic carbon from eutrophic to oligotrophic waters, Mar. Ecol.-Prog. Ser., 299, 7-17, 2005.

Maranon, E., Holligan, P., Varela, M., Mourino, B., and Bale, A. J.: Basin-scale variability of phytoplankton biomass, production and growth in the Atlantic Ocean, Deep-Sea Res. Pt. I, 47, 825857,2000

Marie, D., Partensky, F., Simon, N., Guillou, L., and Vaulot, D.: Flow cytometry analysis of marine picoplankton, in: Living Colors: Protocols in Flow Cytometry and Cell sorting, edited by: Diamond, R. A., DeMaggio S., 421-454, 2000a.

Marie, D., Simon, N., Guillou, L., Partensky, F., and Vaulot, D.: DNA, RNA analysis of phytoplankton by flow cytometry. In: Current Protocols in Cytometry, John Wiley \& Sons, Inc., 1-18, 2000b.

Menzel, D. W. and Ryther, J. H.: The composition of particulate organic matter in the western north Atlantic, Limnol. Oceanogr., 9, 179-186, 1964.

Minster, J. F. and Boulahdid, M.: Redfield ratios along isopycnal surfaces - a complementary study, Deep-Sea Res., 34, 19812003, 1987.

Moore, C. M., Ostrowski, M., Scanlan, D. J., Feren, K., and Sweetsir, T.: Phytoplankton photoacclimation and photoadaptation in response to environmental gradients in a shelf sea, Limnol. Oceanogr., 51, 936-949, 2006.

Moreira-Turcq, P. F., Cauwet, G., and Martin, J. M.: Contribution of flow cytometry to estimate picoplankton biomass in estuarine systems, Hydrobiologia, 462, 157-168, 2001.

Morgan, J. A., Quinby, H. L., and Ducklow, H. W.: Bacterial abundance and production in the western Black Sea, Deep-Sea Res. Pt. II, 53, 1945-1960, 2006.

Moutin, T., Karl, D., Duhamel, S., Rimmelin, P., Raimbault, P., Van Mooy, B. and Claustre, H.: Phosphate availability and the ultimate control of nitrate input by nitrogen fixation in the tropical Pacific Ocean, Biogeosciences Discuss., 4, 2407-2440, 2007, http://www.biogeosciences-discuss.net/4/2407/2007/.

Moutin, T., Raimbault, P., and Poggiale, J.-C.: Production primaire dans les eaux de surface de la Méditerranée occidentale, Calcul de la production journalière, C. R. Académie des Sciences 322, 651-659, 1999.

Moutin, T., Thingstad, T. F., Van Wambeke, F., Marie, D., Slawyk, G., Raimbault, P., and Claustre, H.: Does competition for nanomolar phosphate supply explain the predominance of the cyanobacterium Synechococcus?, Limnol. Oceanogr., 47,
$1562-1567,2002$.

Nalewajko, C. and Garside, C.: Methodological problems in the simultaneous assessment of photosynthesis and nutrient uptake in phytoplankton as functions of light intensity and cell size, Limnol. Oceanogr., 28, 591-597, 1983.

Obernosterer, I., Kawasaki, N., and Benner, R.: P-limitation of respiration in the Sargasso Sea and uncoupling of bacteria from $\mathrm{P}$ regeneration in size-fractionation experiments, Aquat. Microb. Ecol., 32, 229-237, 2003.

Paytan, A., Cade-Menun, B. J., McLaughlin, K., and Faul, K. L.: Selective phosphorus regeneration of sinking marine particles: evidence from 31P-NMR, Mar. Chem., 82, 55-70, 2003.

Perez, V., Fernandez, E., Maranon, E., Moran, X. A. G., and Zubkov, M. V.: Vertical distribution of phytoplankton biomass, production and growth in the Atlantic subtropical gyres, DeepSea Res. Pt. I, 53, 1616-1634, 2006.

Perry, M. J. and Eppley, R. W.: Phosphate uptake by phytoplankton in the central North Pacific Ocean, Deep-Sea Res., 28A, 39-49, 1981.

Philips, E. J., Aldridge, F. J., Schelske, C. L., and Crisman, T. L.: Relationships between light availability, chlorophyll a, and tripton in a large, shallow subtropical lake, Limnol. Oceanogr., 40, 416-421, 1995.

Pirker, H., Pausz, C., Stoderegger, K. E., and Herndl, G. J.: Simultaneous measurement of metabolic activity and membrane integrity in marine bacterioplankton determined by confocal laserscanning microscopy, Aquat. Microb. Ecol., 39, 225-233, 2005.

Pujo-Pay, M. and Raimbault, P.: Improvement of the wet-oxidation procedure for simultaneous determination of particulate organic nitrogen and phosphorus collected on filters, Mar. Ecol.-Prog. Ser., 105, 203-207, 1994.

Quevedo, M. and Anadon, R.: Protist control of phytoplankton growth in the subtropical noth-east Atlantic, Mar. Ecol.-Prog. Ser., 221, 29-38, 2001.

Raimbault, P., Diaz, F., and Boudjellal, B.: Simultaneous determination of particulate forms of carbon, nitrogen and phosphorus collected on filters using a semi-automatic wet-oxidation procedure, Mar. Ecol.-Prog. Ser., 180, 289-295, 1999.

Ras, J., Uitz, J., and Claustre, H.: Spatial variability of phytoplankton pigment distributions in the Subtropical South Pacific Ocean: comparison between in situ and predicted data, Biogeosciences Discuss., 4, 3409-3451, 2007, http://www.biogeosciences-discuss.net/4/3409/2007/.

Redalje, D. G. and Laws, E. A.: A new method for estimating phytoplankton growth rates and carbon biomass, Mar. Biol., 62, 7379, 1981.

Redfield, A. C., Ketchum, B. H., and Richards, F. A.: The influence of organisms on the composition of seawater, in: The Sea, edited by: Hill, M. N., 26-77, 1963.

Revilla, M., Iriarte, A., Madariaga, I., and Orive, E.: Bacterial and Phytoplankton Dynamics along a Trophic Gradient in a Shallow Temperate Estuary, Estuar. Coast. Shelf S., 50, 297-313, 2000.

Riemann, B., Bell, R. T., and Jorgensen, N. O. G.: Incorporation of thymidine, adenine and leucine into natural bacterial assemblages, Mar. Ecol.-Prog. Ser., 65, 87-94, 1990.

Sciandra, A., Gostan, J., Collos, Y., Descola-Gros, C., Leboulanger, C., Martin-Jézéquel, V., Denis, M., Lefèvre, D., CopinMontégut, C., and Avril, B.: Growth-compensating phenomena in continuous cultures of Dunaliella tertiolecta limited simulta- 
neously by light and nitrate, Limnol. Oceanogr., 42, 1325-1339, 1997.

Sherr, E. B., Sherr, B. F., and Sigmon, C. T.: Activity of marine bacteria under incubated and in situ conditions, Aquat. Microb. Ecol., 20, 213-223, 1999.

Sherr, E., Sherr, B., and Cowles, T.: Mesoscale variability in bacterial activity in the Northeast Pacific Ocean off Oregon, USA, Aquat. Microb. Ecol., 25, 21-30, 2001.

Six, C., Thomas, J. C., Brahamsha, B., Lemoine, Y., and Partensky, F.: Photophysiology of the marine cyanobacterium Synechococcus sp. WH8102, a new model organism, Appl. Environ. Microb., 35, 17-29, 2004.

Smith, D. C. and Azam, F.: A simple, economical method for measuring bacterial protein synthesis rates in seawater using $3 \mathrm{H}-$ leucine, Marine Microbial Food Webs, 6, 107-114, 1992.

Smith, J. W. O., Marra, J., Hiscock, M. R., and Barber, R. T.: The seasonal cycle of phytoplankton biomass and primary productivity in the Ross Sea, Antarctica, Deep-Sea Res. Pt. II, 47, 31193140, 2000.

Sobczak, W. V., Cloern, J. E., Jassby, A. D., and Muller-Solger, A. B.: Bioavailability of organic matter in a highly disturbed estuary: The role of detrital and algal resources, PNAS, 99, 8101$8105,2002$.

Steeman-Nielsen, E.: Measurement of production of organic matter in the sea by means of carbon-14, Nature, 267, 684-685, 1951

Strickland, J. D. H. and Parsons, T. R.: A practical handbook of seawater analysis, Bulletin of Fisheries Research Board of Canada, 167, 49-55, 1972.

Taylor, A., Geider, R., and Gilbert, F.: Seasonal and latitudinal dependencies of phytoplankton carbon-to-chlorophyll a ratios: results of a modelling study, Mar. Ecol.-Prog. Ser., 152, 51-66, 1997.

Thingstad, T. F., Riemann, B., Havskum, H., and Garde, K.: Incorporation rates and biomass content of $\mathrm{C}$ and $\mathrm{P}$ in phytoplankton and bacteria in the Bay of Aarhus (Denmark) June 1992, J. Plankton Res., 18, 97-121, 1996.

Thingstad, T. F.: Control of bacterial growth in idealized food webs, in: Microbial ecology of the oceans, edited by: Kirchman, D. L., Wiley series in Ecological and Applied Microbiology, Mitchekk, R. (Series Ed.), 229-260, 2000.

Tremblay, J. and Legendre, L.: A model for the size-fractionated biomass and production of marine phytoplankton, Limnol. Oceanogr., 39, 2004-2014, 1994.

Uitz, J., Claustre, H., Morel, A., and Hooker, S. B.: Vertical distribution of phytoplankton communities in open ocean: An assessment based on surface chlorophyll, J. Geophys. Res., 111, doi:10.1029/2005JC003207, 2006.
Vadstein, O., Jensen, A., Olsen, Y., and Reinertsen, H.: Growth and phosphorus status of limnetic phytoplankton and bacteria, Limnol. Oceanogr., 33, 489-503, 1988.

Van Mooy, B. A. S., Rocap, G., Fredricks, H. F., Evans, C. T., and Devol, A. H.: Sulfolipids dramatically decrease phosphorus demand by picocyanobacteria in oligotrophic marine environments, PNAS, 103, 8607-8612, 2006.

Van Wambeke, F., Bonnet, S., Moutin, T., Raimbault, P., Alarçon, G., and Guieu, C.: Factors limiting heterotrophic bacterial production in the southern Pacific Ocean, Biogeosciences Discuss., 4, 3799-3828, 2007a.

Van Wambeke, F., Obernosterer, I., Moutin T., Duhamel S., Ulloa O., and Claustre, H.: Heterotrophic bacterial production in the South East Pacific: longitudinal trends and coupling with primary production, Biogeosciences Discuss., 4, 2761-2791, 2007b.

Vaulot, D.: Estimate of phytoplankton division rates by the mitotic index method: The fmax approach revisited, Limnol. Oceanogr., 37, 644-649, 1992.

Veldhuis, M. J. W. and Kraay, G. W.: Phytoplankton in the subtropical Atlantic Ocean: towards a better assessment of biomass and composition, Deep-Sea Res. Pt. I, 51, 507-530, 2004.

Watson, S. W., Novitsky, T. J., Quinby, H. L., and Valois, F. W.: Determination of bacterial number and biomass in the marine environment, Appl. Environ. Microb., 33, 940-946, 1977.

Welschmeyer, N. A., Goericke, R., Strom, S., and Peterson, W. T.: Phytoplankton growth and herbivory in the subarctic Pacific: a chemotaxonomic analysis, Limnol. Oceanogr., 36, 1631-1649, 1991.

Welschmeyer, N. A.: Fluorimetric analysis of chlorophyll a in the presence of chlorophyll $b$ and pheopigments, Limnol. Oceanogr., 39, 1985-1992, 1994.

Wood, A. M., Rai, H., Garnier, J., Kairesalo, T., Gresens, S., Orive, E., and Ravail, B.: Practical approaches to algal excretion, Marine Microbial Food Webs, 6, 21-38, 1992.

Zubkov, M. V., Sleigh, M. A., Burkill, P. H., and Leakey, R. J. G.: Picoplankton community structure on the Atlantic Meridional Transect: a comparison between seasons, Prog. Oceanogr., 45, 369-386, 2000.

Zweifel, U. L. and Hagstrom, A.: Total Counts of Marine Bacteria Include a Large Fraction of Non-Nucleoid-Containing Bacteria (Ghosts), Appl. Environ. Microbiol., 61, 2180-2185, 1995. 